Article

\title{
Burned-Area Detection in Amazonian Environments Using Standardized Time Series Per Pixel in MODIS Data
}

\author{
Níckolas Castro Santana ${ }^{1}$, Osmar Abílio de Carvalho Júnior ${ }^{2, *}$, \\ Roberto Arnaldo Trancoso Gomes ${ }^{2} \mathbb{D}$ and Renato Fontes Guimarães ${ }^{2} \mathbb{D}$ \\ 1 Departamento de Geografia Campus Universitário Darcy Ribeiro, Asa Norte, Universidade de \\ Brasília (UnB), DF 70910-900, Brasília, Brazil; nickolas.santana@outlook.com \\ 2 Departamento de Geografia Campus Universitário Darcy Ribeiro, Asa Norte, Universidade de \\ Brasília (UnB), DF 70910-900, Brasília, Brazil; robertogomes@unb.br (R.A.T.G.); renatofg@unb.br (R.F.G.) \\ * Correspondence: osmarjr@unb.br; Tel.: +55-61-3367-5001
}

Received: 28 September 2018; Accepted: 4 November 2018; Published: 29 November 2018

\begin{abstract}
Fires associated with the expansion of cattle ranching and agriculture have become a problem in the Amazon biome, causing severe environmental damages. Remote sensing techniques have been widely used in fire monitoring on the extensive Amazon forest, but accurate automated fire detection needs improvements. The popular Moderate Resolution Imaging Spectroradiometer (MODIS) MCD64 product still has high omission errors in the region. This research aimed to evaluate MODIS time series spectral indices for mapping burned areas in the municipality of Novo Progresso (State of Pará) and to determine their accuracy in the different types of land use/land cover during the period 2000-2014. The burned area mapping from 8-day composite products, compared the following data: near-infrared (NIR) band; spectral indices (Burnt Area Index (BAIM), Global Environmental Monitoring Index (GEMI), Mid Infrared Burn Index (MIRBI), Normalized Burn Ratio (NBR), variation of Normalized Burn Ratio (NBR2), and Normalized Difference Vegetation Index (NDVI)); and the seasonal difference of spectral indices. Moreover, we compared the time series normalization methods per pixel (zero-mean normalization and Z-score) and the seasonal difference between consecutive years. Threshold-value determination for the fire occurrences was obtained from the comparison of MODIS series with visual image classification of Landsat Thematic Mapper (TM), Enhanced Thematic Mapper Plus (ETM+), and Operational Land Imager (OLI) data using the overall accuracy. The best result considered the following factors: NIR band and zero-mean normalization, obtaining the overall accuracy of $98.99 \%$, commission errors of $32.41 \%$, and omission errors of $31.64 \%$. The proposed method presented better results in burned area detection in the natural fields (Campinarana) with an overall accuracy value of $99.25 \%$, commission errors of $9.71 \%$, and omission errors of $27.60 \%$, as well as pasture, with overall accuracy value of $99.19 \%$, commission errors of $27.60 \%$, and omission errors of $34.76 \%$. Forest areas had a lower accuracy, with an overall accuracy of $98.62 \%$, commission errors of $23.40 \%$, and omission errors of $49.62 \%$. The best performance of the burned area detection in the pastures is relevant because the deforested areas are responsible for more than $70 \%$ of fire events. The results of the proposed method were better than the burned area products (MCD45, MCD64, and FIRE-CCI), but still presented limitations in the identification of burn events in the savanna formations and secondary vegetation.
\end{abstract}

Keywords: fire; forest fires; fire regime; time series; remote sensing; Amazon forest 


\section{Introduction}

Human disturbance is the primary cause of burned events in the Amazon Forest, mainly in areas of deforestation, agriculture, and pastures [1-4]. Anthropogenic fire from farming and livestock usually escapes into neighboring forest areas, resulting in large-scale fire events [5]. Therefore, land-use determines the burning patterns of the Amazon forest, where areas with intense deforestation, fragmentation, and the presence of highways have a higher number of fires, whilst Conservation Units and Indigenous Reserves are essential barriers [6-10]. The Amazon forest has a high vulnerability to fire incidences due to the following factors: most species do not tolerate recurrent fire events, floristic and structural changes, and organic matter incineration that is essential for the maintenance of ecological processes [11-13].

The concentration of Amazon forest fires is along an area called the arc of deforestation, which presents an intensification of anthropogenic actions along the eastern and southern forest edges. Compared with the central zones of the forests, the arc of deforestation has lower biomass and drier climate resulting in larger burnings [14,15]. During severe drought periods, there is an increase in tree mortality on forest edges and the accumulation of dry leaves [16,17], which favor fire events mainly in degraded forests [18-20]. Models of climate change in the Amazon rainforest provide for the expansion of fires due to more frequent droughts and land use intensification [4,21].

In the monitoring of the Amazon Forest ( 5.5 million $\left.\mathrm{km}^{2}\right)$, the use of remote sensing data is necessary due to its synoptic view, rapidity, and high cost-effectiveness. The major impediment to optical remote sensing in the Amazon region is the high atmospheric interference from cloud cover and aerosols [22]. Therefore, high temporal resolution optical sensors are essential for the monitoring of Amazon forest fires, increasing the possibility of acquiring good quality images without atmospheric interference [23-25]. Among the high temporal resolution sensors, the Moderate Resolution Imaging Spectroradiometer (MODIS) sensor has been prominent in the mapping of fires in the different terrestrial biomes [26-28], offering global scale products of active fires [29,30] and burned areas [26,29]. Active fire detection captures the energy emission using thermal infrared imagery (3.6-12 $\mu \mathrm{m}$ range), and provides information only of burning pixels during the passage of the satellite, not allowing the burned area quantification [26,29,31]. In contrast, the post-fire mapping evidenced by ash, coal, and vegetation changes enable obtaining of the perimeter, area, and an estimate of damage caused by forest fires. Thus burned area products (MODIS-MCD45/MCD64) were extensively used in diversity studies about ecosystem structure change and biomass burning emissions [24,32-34]. Padilla et al. [35] performed a validation of the MCD45 and MCD64 products for several terrestrial biomes, obtaining estimated commission errors rates of $46 \%$ and $42 \%$, and omission error rates of $72 \%$ and $68 \%$ for MCD45 and MCD64, respectively. Therefore, the burned area product tends to underestimate the extent of the burned area, where the omission errors were higher than commission errors [35-38]. Cardozo et al. [39] showed that the MODIS burned area product (MCD45) in the Amazon region at different dates, presents values higher than $90 \%$ of omission errors, which corresponds to low accuracy and a need for the development of new algorithms adjusted for this region.

Different remote sensing methods have been proposed for the burned area mapping. The most widely used processing using bi-temporal images combines two algebraic operations: (a) Spectral index calculation, where the most commonly used are the Normalized Burn Ratio (NBR) [40] and Normalized Difference Vegetation Index (NDVI) [41]; and (b) Seasonal differences between the preand post-burned indices, such as dNDVI [42] and dNBR [40]. Other indices have been proposed such as the Burned Area Index Modified (BAIM) [43], Global Environmental Monitoring Index (GEMI) [44], Mid-Infrared Burned Index (MIRBI) [45], and the variation of Normalized Burn Ratio (NBR2) [46].

The adaptation of the index differentiation method to long-term MODIS time series [47,48] considers the entire time series of one year with its antecedent, generating an image set rather than just a single difference image from a custom selection. However, the automatic difference over the time series shows a significant increase in signal-to-noise ratio, with respect to the bi-temporal images that were pre-defined by the analyst. Therefore, the application of the differencing method in continuous 
time series requires methodological improvements [47,48]. Lhermitte et al. [49] tried to solve this problem by selecting control pixels surrounding the unburned area based on time series similarity. This approach considers the spatial context (neighboring pixels) to minimize the external influences and phenological variations [50]. However, this method has severe limitations for complete automation, requiring supervision for not including neighboring pixels with different characteristics as compared to the analyzed pixel.

A proposed alternative is the use of normalized time series using the Z-score (mean zero and standard deviation equal to 1) or means (mean zero), which allow highlighting of the burned areas without changing the signal-to-noise ratio [47]. The normalization procedure is very promising because it does not require neighboring control pixels, considering only the time series of the pixel. This method is different from that proposed by the research of Diáz-Delgado et al. [50] and Lhermitte et al. [49], because it is fast and simple data processing restricted to the pixel, which generates an image that emphasizes the burning points in different environments.

The present paper aims to evaluate and compare different methods of burned area mapping from MODIS time series (BAIM, GEMI, MIRBI, NBR, NBR2, NDVI, and the near-infrared band) and normalized time series per pixel (Mean and Z-Score) in different land covers in the municipality of Novo Progresso, belonging to the Amazon region. This research also evaluates the spatial and temporal distribution of fire in different land use types.

\section{Study Area}

The study area is the municipality of Novo Progresso and surroundings $\left(74,552.1518 \mathrm{~km}^{2}\right)$, State of Pará, Southeast Brazilian Amazon (Figure 1). The climate is Humid Equatorial with annual precipitation ranging from $2050 \mathrm{~mm}$ to $2650 \mathrm{~mm}$ and average temperature above $25{ }^{\circ} \mathrm{C}$ [51,52]. The rainy season is from November to May and the dry season, from June to October, when most fire events occur [53].

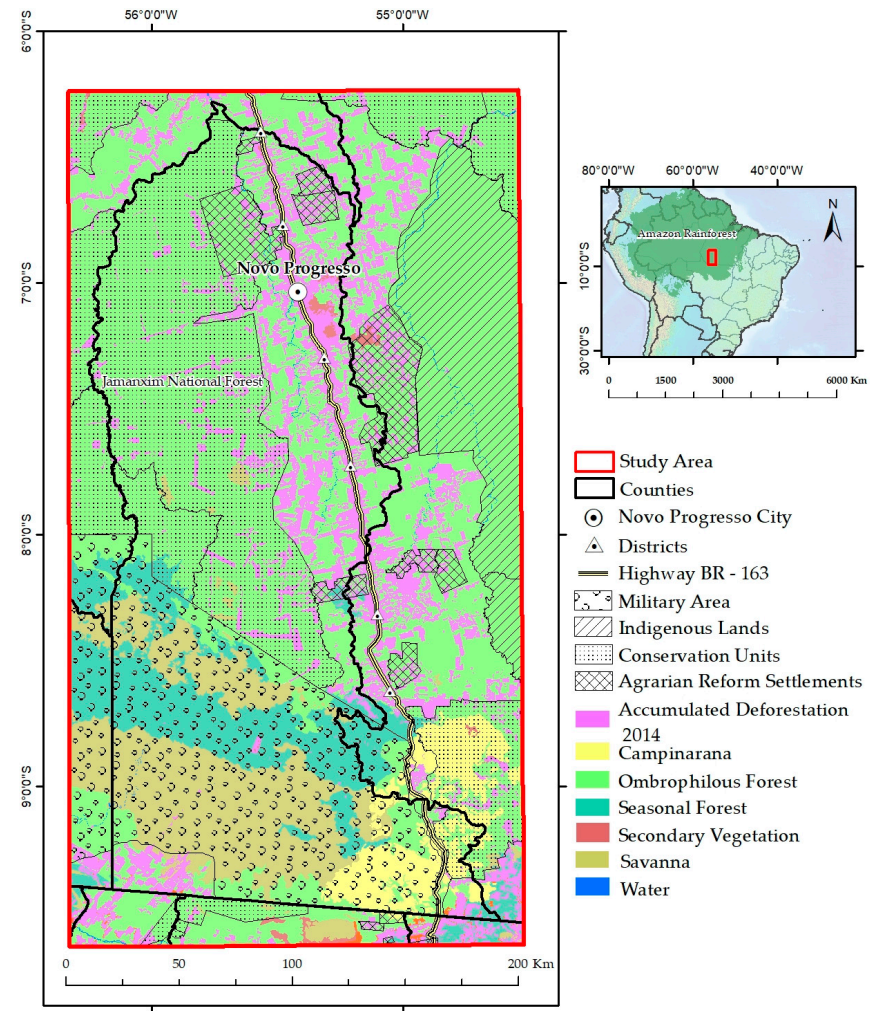

Figure 1. Location of the study area, showing the territorial units and the land-use and land-cover types derived from the following data: Land Use [54,55], Conservation Units [56], Indigenous Lands [57], Land Reform Settlements [58], and Military Area [59]. 
The predominant vegetation is classified as Open Ombrophilous Sub-Montane Forest, but it also contains areas of Forest Savanna and Submontane Semideciduous Seasonal Forest [55]. This region has been inhabited by indigenous populations, currently restricted to the Baú and Menkragnoti Indigenous Reserves [60]. The construction of the federal highway BR-163 in the 1980s brought an intense migratory flow that increased the soybean cultivation, livestock, and infrastructure projects [61]. The Conservation Units curb deforestation growth within Integral Protection Units (Rio Novo National Park, Cristalino State Park, Nascentes da Serra do Cachimbo Biological Reserve, and Crystal Private Reserve Natural Heritage) and Sustainable Use Units (Jamanxim and Altamira National Forests, Iriri State Forest and Tapajós Environmental Protection Area) [56]. The Agrarian Reform Settlements and Military Areas complement the federal land types of the region $[58,59]$. The leading causes of fire are deforestation and pasture maintenance [2,9].

\section{Materials and Methods}

\subsection{Methodology Flowchart}

The methodology adopted the following steps, including MODIS 8-day composites data acquisition (MOD09A1 and MOD09Q1), calculation of spectral indices, filtering, time series normalization, burned area mapping, and validation (Figure 2). The research calculated seven spectral indices and applied in each index two types of time series normalization per pixel (Z-score and zero-mean) and the seasonal difference method, computing a total of 21 different procedures. Finally, we compared the burned areas by the different MODIS image processing with the following data: Visual interpretation of Landsat images (Thematic Mapper (TM)/ Enhanced Thematic Mapper Plus $(\mathrm{ETM}+)$ /Operational Land Imager (OLI)) and burned area products (MCD45 [31], MCD64 [26], and Fire CCI) $[62,63]$.

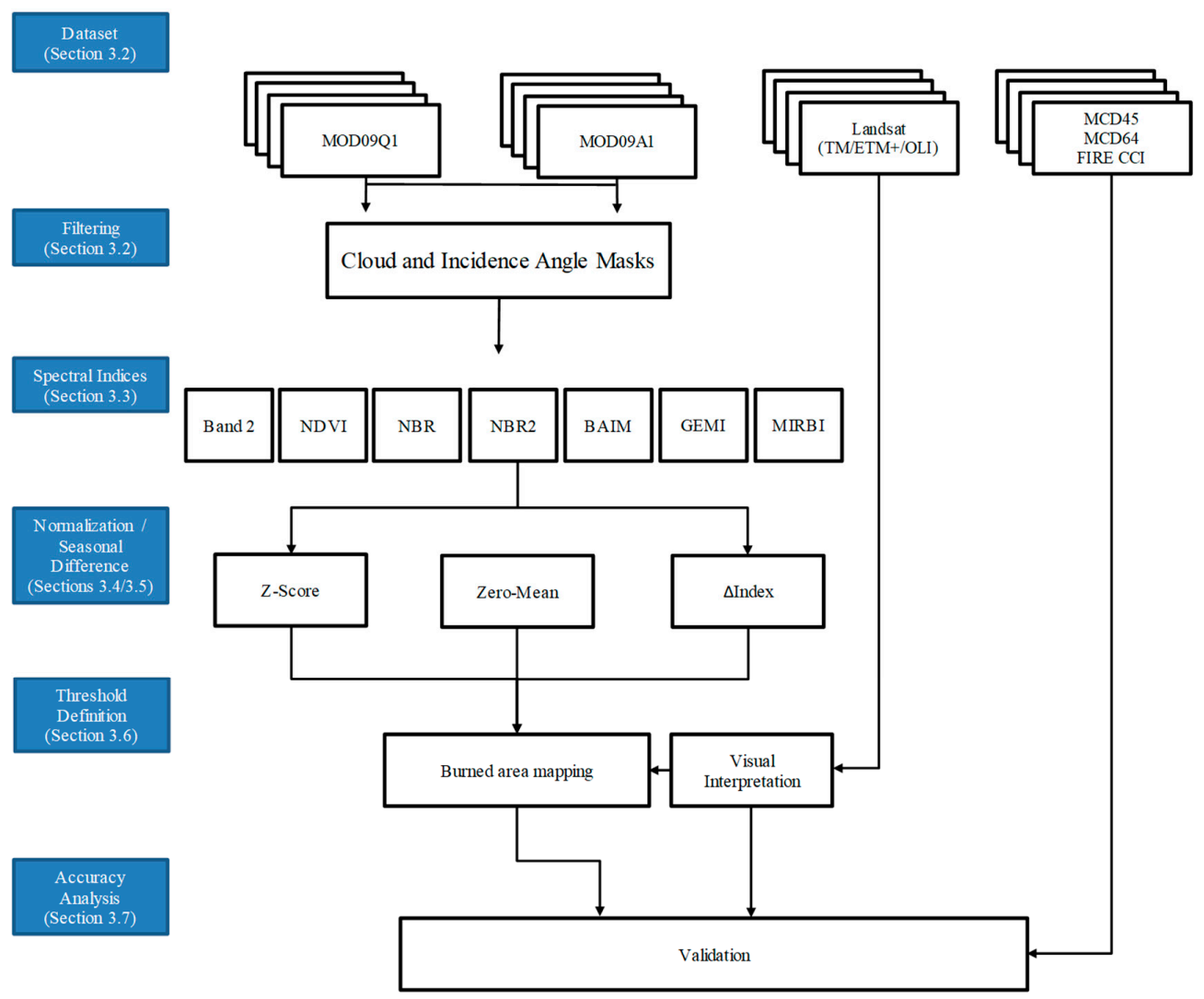

Figure 2. Methodology flowchart. 


\subsection{MODIS Data}

The MODIS sensor aboard the Terra and Aqua satellites was developed by the National Aeronautics and Space Administration (NASA) to provide continuous observations of the Earth's surface [64]. This sensor has 36 spectral bands ranging from $0.4 \mu \mathrm{m}$ to $14.4 \mu \mathrm{m}$ at three spatial resolutions (250, $500 \mathrm{~m}$, and $1 \mathrm{~km}$ ) according to the band. We used the following MODIS products: (a) 8-day composite surface reflectance at 250 and 500-m resolution (MOD09A1 and MOD09Q1); (b) daily burned area at 500-m resolution (MCD45A1) [31]; (c) daily burned area at 500-m resolution (MCD64A1) [26], and (d) monthly burned area product at 300-m resolution derived from both MODIS and Medium Resolution Imaging Spectrometer (MERIS) sensors (FIRE CCI) [62,63]. The data download sites were the NASA Land Data Products and Services website (https: / / search.earthdata.nasa.gov/) and from the European Space Agency (ESA) Fire CCI website (http:/ / www.esa-fire-cci.org/).

MODIS surface reflectance product is composed by bands $1-2(0.6 \mu \mathrm{m}-0.9 \mu \mathrm{m})$ at $250-\mathrm{m}$ spatial resolution and bands 3-7 $(0.4 \mu \mathrm{m}-2.1 \mu \mathrm{m})$ at 500-m spatial resolution [65]. These images are available as daily data and 8-day composite product that select the best observation within the time interval and eliminate the presence of artifacts such as cloud or cloud shadow. The traditional temporal composite based on the maximization of values can cause loss of information of burned areas, which are characterized by low albedo [66]. In contrast, daily images have more noise and atmospheric effects that can also lead to the insertion of invalid information.

The acquisition of MODIS data covered the period 2000-2014, resulting in 683 8-day composite images. We discarded the poor-quality pixels with (a) cloud coverage, (b) related to the high and medium aerosol classes, and (c) relative to frontal scattering and with zenith angles greater than $60^{\circ}$, because of the influence of the spectral mixing of the targets with their shadows, especially in the near-infrared (NIR) band [66,67]. We converted the MODIS images from native sinusoidal projection to the Universal Transverse Mercator (UTM, WGS 84 ellipsoid) projection. Spectral bands with the spatial resolution of $500 \mathrm{~m}$ were resampled at $250 \mathrm{~m}$ using the nearest neighbor interpolation method to make the data compatible.

\subsection{Spectral Indices}

The data compared to the fire detection were: (a) Only the NIR band (band 2); (b) NDVI, NBR, NBR2, BAIM, GEMI, and MIRBI index; and (c) temporal differencing $(\Delta)$ (Table 1). The NIR band allows a high separation of the burned areas compared to other spectral channels [68,69]. The NDVI uses the RED and NIR bands, and is widely used to highlight vegetation changes [70]. The NBR index developed to highlight burned areas adopts the normalized difference between the NIR and Short Wave Infrared (SWIR) [40]. The NBR2 and MIRBI indices are variations of the NBR and NDVI indices, considering the SWIR1 and SWIR channels to highlight the burn areas [45,46]. The BAIM index maximizes the spectral deviation between the burned area and other land covers from the NIR and SWIR channels [43]. The GEMI index was determined to evaluate the vegetation conditions, reducing the content of both the NIR and RED channels [45].

Seasonal differencing is a change detection method with extensive use in the analysis of the severity of a fire $[47,48,71-73]$. This method consists of subtracting the values of spectral indices or bands acquired before and after a fire event (pre-fire minus post-fire) to emphasize the changes related to the fire. The advantage of the method is the possibility of defining the fire severity, apart from indicating the areas with vegetation regeneration [46]. Despite the proven utility of the technique in many different environments, there are few details about its application in the Amazon region or other areas of tropical forests. Seasonal differencing techniques have been used with different spectral indices including: $\triangle$ NBR [48,74], $\triangle$ NDVI [75], $\triangle$ NBR2 [76], $\triangle$ BAIM [74], $\triangle$ GEMI [77], and $\triangle$ MIRBI [78]. 
Table 1. Spectral indices to highlight the burned areas adopted in this research.

\begin{tabular}{ccc}
\hline Index & Equation & Bibliographic Reference \\
\hline $\mathrm{NBR} / \triangle \mathrm{NBR}$ & $N B R=\frac{N I R-S W I R 2}{N I R+S W I R 2}$ & {$[40,79]$} \\
$\mathrm{NDVI} / \Delta \mathrm{NDVI}$ & $N D V I=\frac{N I R-R E D}{N I R+R E D}$ & {$[41]$} \\
$\mathrm{NBR} 2 / \Delta \mathrm{NBR} 2$ & $N B R 2=\frac{S W I R 1-S W I R 2}{S W I R 1+S W I R 2}$ & {$[46]$} \\
$\mathrm{BAIM} / \Delta \mathrm{BAIM}$ & $B A I M=\frac{1}{(0.05-N I R)^{2}+(0.2-S W I R 2) 2}$ & {$[43]$} \\
$\mathrm{GEMI} / \Delta \mathrm{GEMI}$ & $G E M I=n(1-0.25 n)-\frac{R E D-0.125}{1-R E D}$ & {$[44]$} \\
$\mathrm{MIRBI} / \Delta \mathrm{MIRBI}$ & $M I R B I=(10 * S W I R 2)-(9.8 * S W I R 1)+2$ & {$[45]$} \\
$\Delta$ & prefire - postfire & \\
\hline \multicolumn{3}{c}{ Notes: In GEMI $n=\frac{2\left(N I R^{2}-R E D^{2}\right)+1.5_{N I R}+0.5_{R E D}}{N I R+R E D+0.5}$}
\end{tabular}

\subsection{Time Series Standardization per Pixel}

The burned areas show differences in spectral behavior according to the vegetation type and the period after the fire [80]. In the Amazon, burning occurs mostly in pasture and agriculture, but there are significant impacts on forest and savanna areas [81,82]. Therefore, the detection of areas burned by remote sensing should be adaptable for environmental differences. The normalized time series allows to equate the behavior of distinct vegetation and highlight the burned areas [83]. The normalization procedures consider the temporal data per pixel. The two evaluated methods of time series normalization were: Zero-mean (mean equal to 0 ) and Z-score (mean equal to 0 and standard deviation equal to 1 ) expressed by the following formulations:

$$
\begin{gathered}
\text { Zero }- \text { mean }=x_{t}-\mu \\
Z-\text { score }=\frac{x_{t}-\mu}{\sigma}
\end{gathered}
$$

where $x$ is the pixel value, $t$ is the time, $\mu$ is the mean of the remote sensing data over time $(t)$ for a pixel, and $\sigma$ is its standard deviation. Therefore, the two normalization methods present negative values when the remote sensing values are smaller than the temporal mean and positive values when they are above. The Z-score approach was successful for burned area detection in regions of savanna vegetation [83]. Normalization makes the burned-area features of different environments compatible and eliminates confusion with low-albedo targets (e.g., water). As an example, we compared the MODIS NIR temporal series of water bodies with burned areas in natural fields (Campinarana), grasslands, and wooded savannas, showing an overlap of values and the inability to distinguish different targets by a single threshold value (Figure 3a). The time series normalized by the mean allows separating the burned area and water bodies by a single threshold (Figure 3b). Moreover, the Ombrophilous forests have reflectance values in the NIR range that are higher than the seasonal forests and forested savannas, which remain higher even after a fire event and prevent the use of a single threshold for the detection of burning among these types of vegetation (Figure 4a). The method of time series normalization equalizes the fire points. Thus, forest time series normalized by the mean decrease false fire events significantly, but the omission of some points occurs mainly in the seasonal forest and forested savanna (Figure $4 b$ ). 

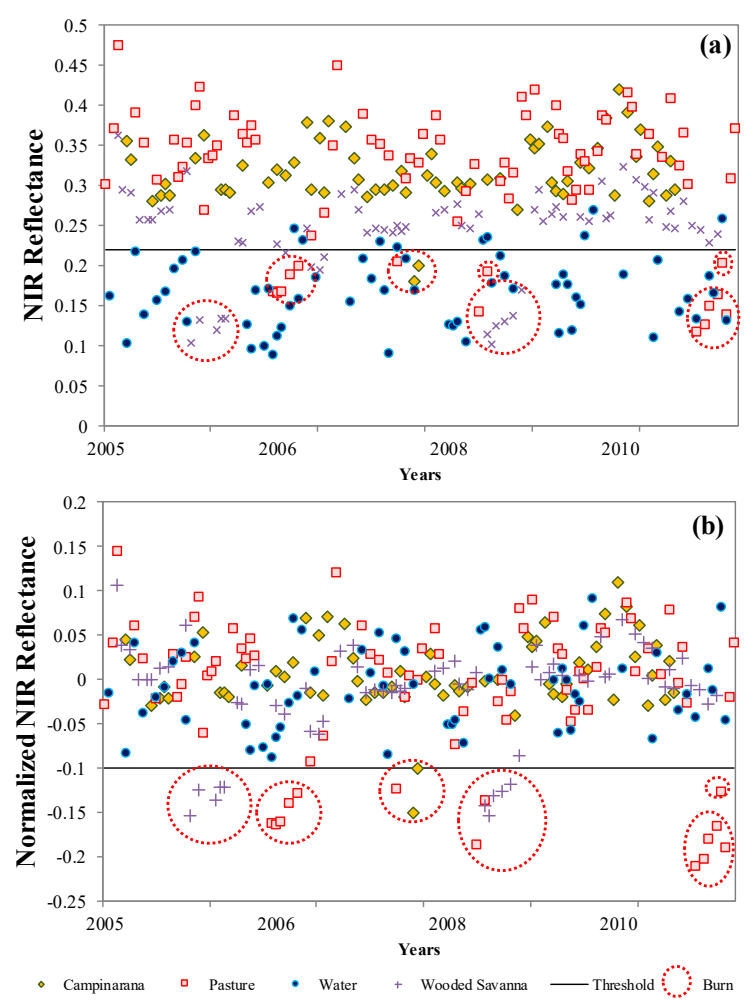

Figure 3. Comparison of MODIS near-infrared time series for different burned and unburned targets within Campinarana, Pasture, Water and Wooded Savanna: (a) without normalization; (b) with zero-mean normalization. Missing values are masked pixels.
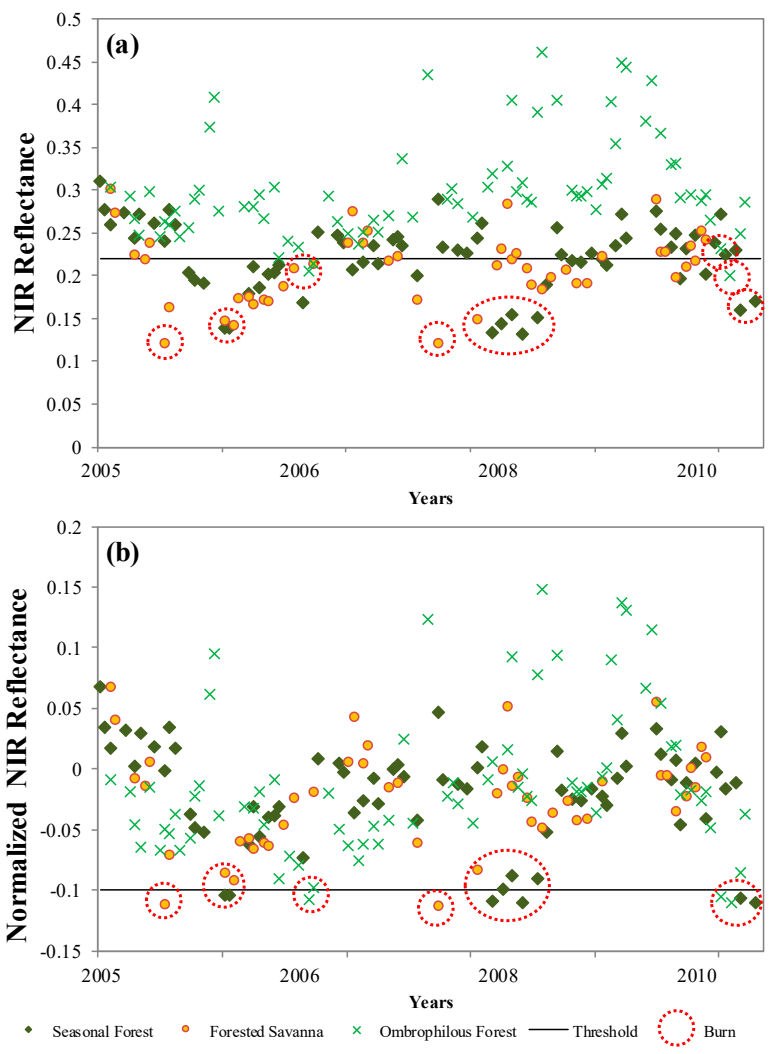

Figure 4. Comparison of MODIS near-infrared time series for different burned and unburned targets within Seasonal Forest, Forested Savanna, and Ombrophilous Forest: (a) without normalization; (b) with zero-mean normalization. Missing values are masked pixels. 
In addition to the relevant results in the time dimension, normalization per pixel also causes a significant digital enhancement of the burned areas in the spatial dimension. In images without normalization, the savanna and watercourses have similar values to the burned areas, being confused in the application of a threshold value (Figure 5a). The normalized image allows an apparent distinction between the burned areas compared to water bodies, since they have significantly lower values (Figure 5b).

(A) NIR: 02 September 2010 - Original

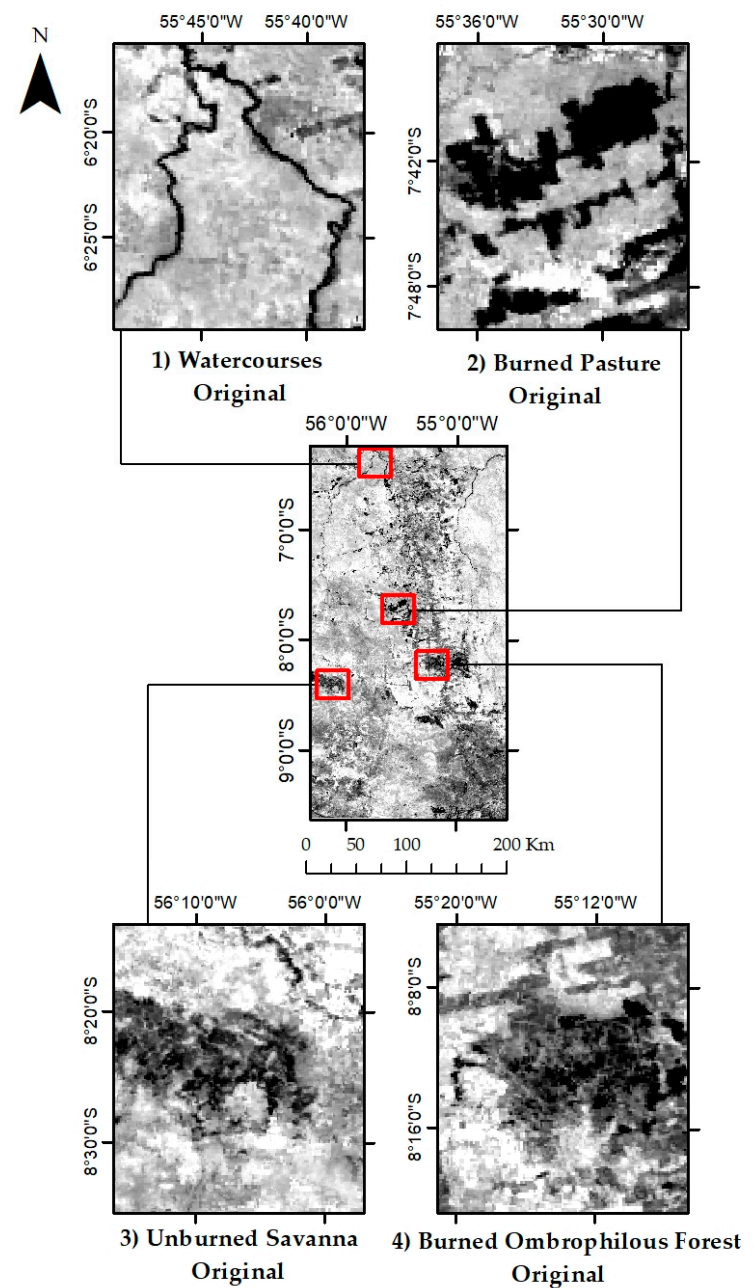

(B) NIR: 02 September 2010 - Zero-Mean Normalization

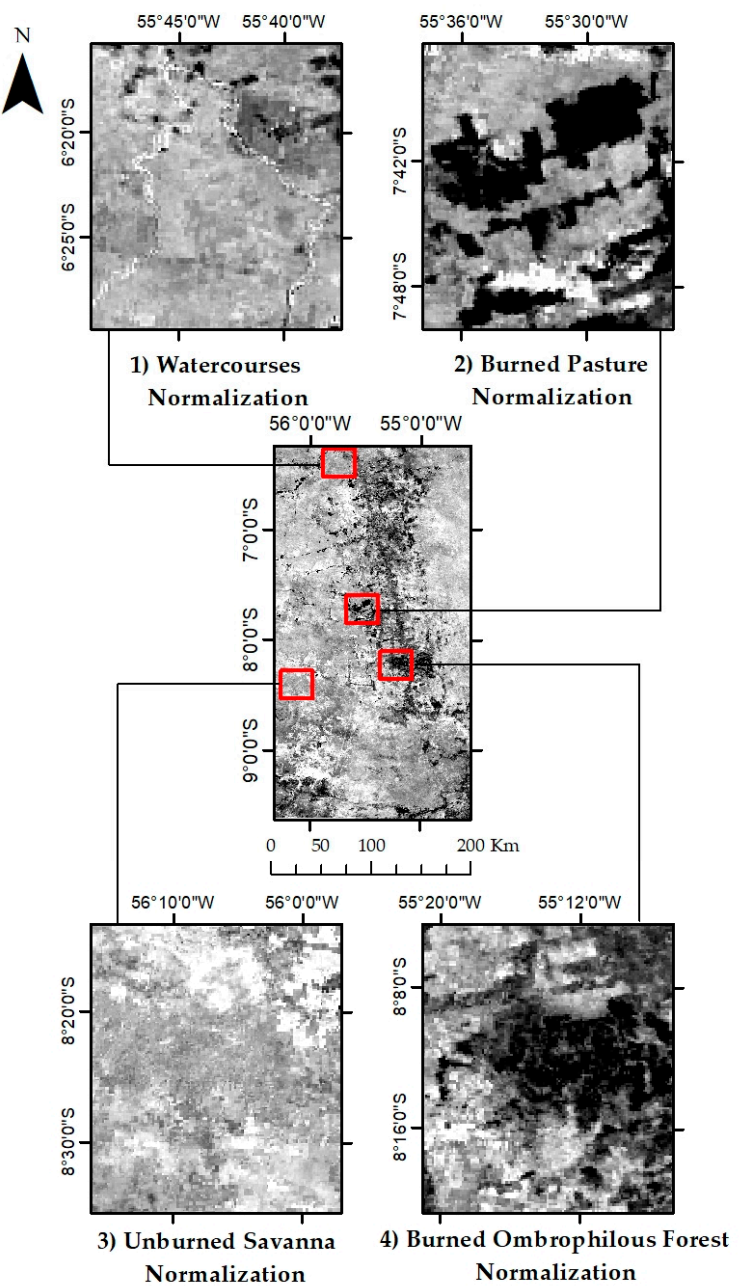

Figure 5. Exemplification of digital enhancement using normalized time series of the near-infrared band. (A) without normalization; (B) with zero-mean normalization. The zero-mean normalization allows the distinction between burned and unburned targets.

\subsection{Seasonal Differencing}

The seasonal difference is one of the most commonly used methods for the detection of burned areas, but studies focus on bi-temporal analysis based on preselected images. Therefore, most studies adopt a specific fire event, where selection by the analyst of two images near the birthday dates considers the low presence of clouds or noises. Few studies detect areas burned by seasonal differences in long-term time series of satellite images, using tens or hundreds of images. The seasonal difference algorithms in long time series assume fixed time intervals and present a certain amount of random noise, since it is impossible to get multiple cloudless and noise-free images on birthday dates in different years [47-49,83]. Thus, some proposals have been made to mitigate interference, considering spatial and temporal dimensions. A spatial approach involves selecting control pixels for pre-fire data 
by examining the contextual neighborhood around the focal pixel and averaging two or more similar pixels within spatial windows [84,85]. A temporal approach involves the use of the average of the birthday data of the complete time series rather than the simple data from the previous year $[47,83]$.

In this research, the seasonal differencing considered two strategies: (a) Automatic method with a fixed annual interval, where a pre-fire image was subtracted from the post-fire with a range of one year exactly; and (b) Method to select a good quality image closer to the anniversary date when the previous year's image had poor quality or cloud coverage. The latter option may have non-fixed subtraction intervals, performing the temporal search for a better-quality pixel within a time window.

\subsection{Landsat Reference Data and Burned Area Mapping}

The threshold definition for separation between burned and unburned areas used the method developed by Carvalho Júnior et al. [83]. This procedure compares a reference map of the burned areas, previously obtained from an image with better spatial resolution, and the burned areas acquired by a sequence of thresholds from a spectral band or spectral index. Thus, the method generates an overall accuracy curve from the comparison of the reference map and the classifications using threshold values (Figure 6). The fire detection in other time series images used the threshold value with the best overall accuracy. In this research, the definition of the best threshold used seven reference maps of the burned area produced by the visual interpretation of the Landsat TM and ETM+ images on the following dates: 15/08/2001, 19/09/2002, 28/07/2003, 30/07/2004, 03/09/2005, 10/08/2008, and 01/09/2010 (Table 2, Figure 7). The acquisition of Landsat data came from the United States Geological Survey (USGS) website (https:/ / earthexplorer.usgs.gov/). The visual image interpretation methodology [35,86] used at least two different dates to identify burned areas and exclude false positives. The fires in the region occur mainly during the dry season, where there is more availability of cloudless images and Landsat/MODIS pairs with matching dates, avoiding the possible omission of fires due to different dates.

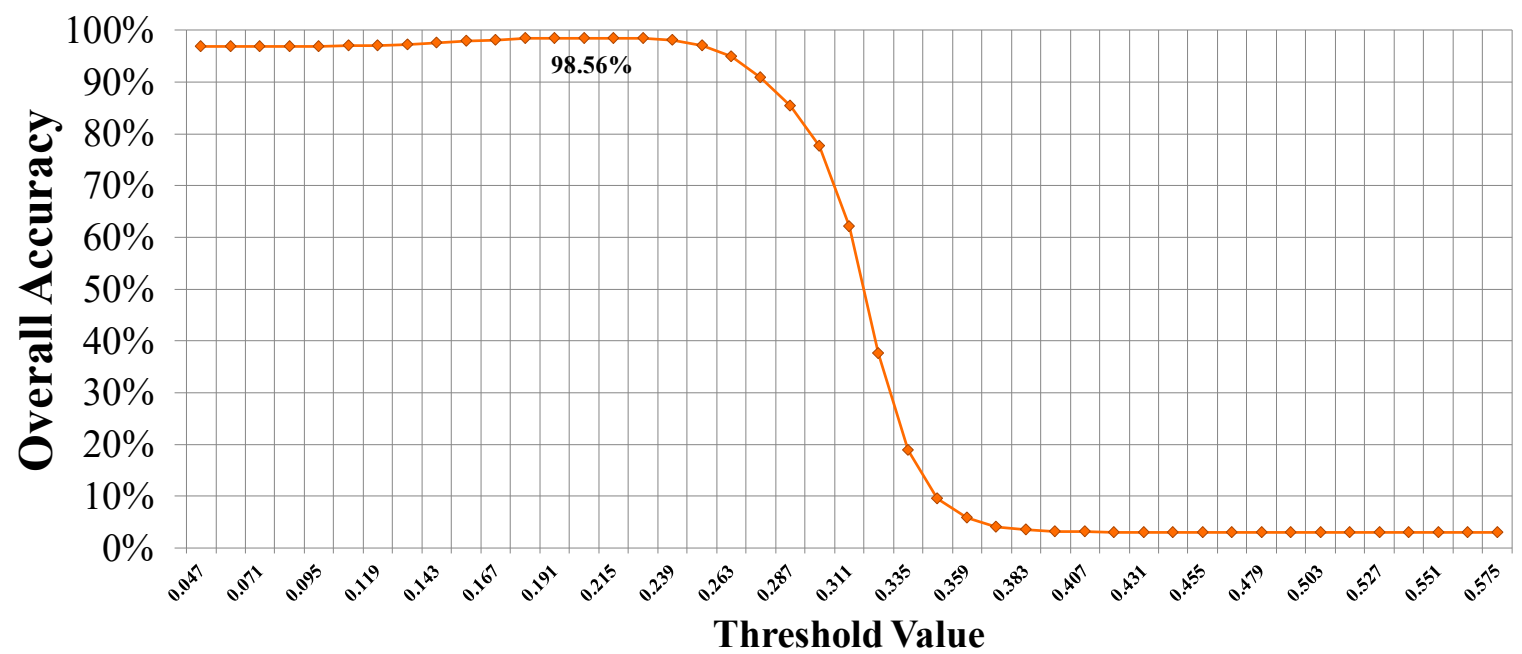

Figure 6. Example of the overall accuracy curve between the burned areas from the visual interpretation of Landsat-5 TM image (30/07/2004) and the results from the classifications using different thresholds in the MODIS near-infrared band. The optimal threshold is 0.215 in the band 2 image (overall accuracy of $98.56 \%)$.

The tests covered an area corresponding to $20 \%$ of the study area $\left(14,689.638 \mathrm{~km}^{2}\right)$, containing the highest rate of deforestation and burning in the analyzed image set. The images included three classes: burned area, unburned area, and low-quality pixels (clouds and noise) from the quality mask available with Landsat images on the EarthExplorer site (Table 2). The seasonal difference with the fixed interval presupposes the image selection with exactly one previous year, being able to have a high percentage 
of pixels with atmospheric interference. The seasonal difference with the closest high-quality image selects data with the lowest cloud coverage within a user-stipulated period.

Table 2. Low-quality pixel percentage of Landsat scenes used to define the threshold value.

\begin{tabular}{lcccc}
\hline \multirow{2}{*}{$\begin{array}{c}\text { Image } \\
\text { Date }\end{array}$} & Sensor & \multicolumn{4}{c}{ Percentage of Low-Quality Pixels } \\
\cline { 3 - 5 } & $\begin{array}{c}\text { Normalization } \\
\text { Method }\end{array}$ & $\begin{array}{c}\text { Seasonal Difference } \\
\text { (Fixed Interval) }\end{array}$ & $\begin{array}{c}\text { Seasonal Difference (Closest } \\
\text { High-Quality Image) }\end{array}$ \\
\hline $15 / 08 / 2001$ & ETM+ & $34 \%$ & - & - \\
\hline $19 / 09 / 2002$ & ETM+ & $25 \%$ & $77 \%$ & $19 \%$ \\
\hline $28 / 07 / 2003$ & TM & $13 \%$ & $82 \%$ & $24 \%$ \\
\hline $30 / 07 / 2004$ & TM & $44 \%$ & $51 \%$ & $13 \%$ \\
\hline $03 / 09 / 2005$ & TM & $26 \%$ & $51 \%$ & $12 \%$ \\
\hline $10 / 08 / 2008$ & TM & $47 \%$ & $57 \%$ & $45 \%$ \\
\hline $01 / 09 / 2010$ & TM & $7 \%$ & $49 \%$ & $22 \%$ \\
\hline
\end{tabular}

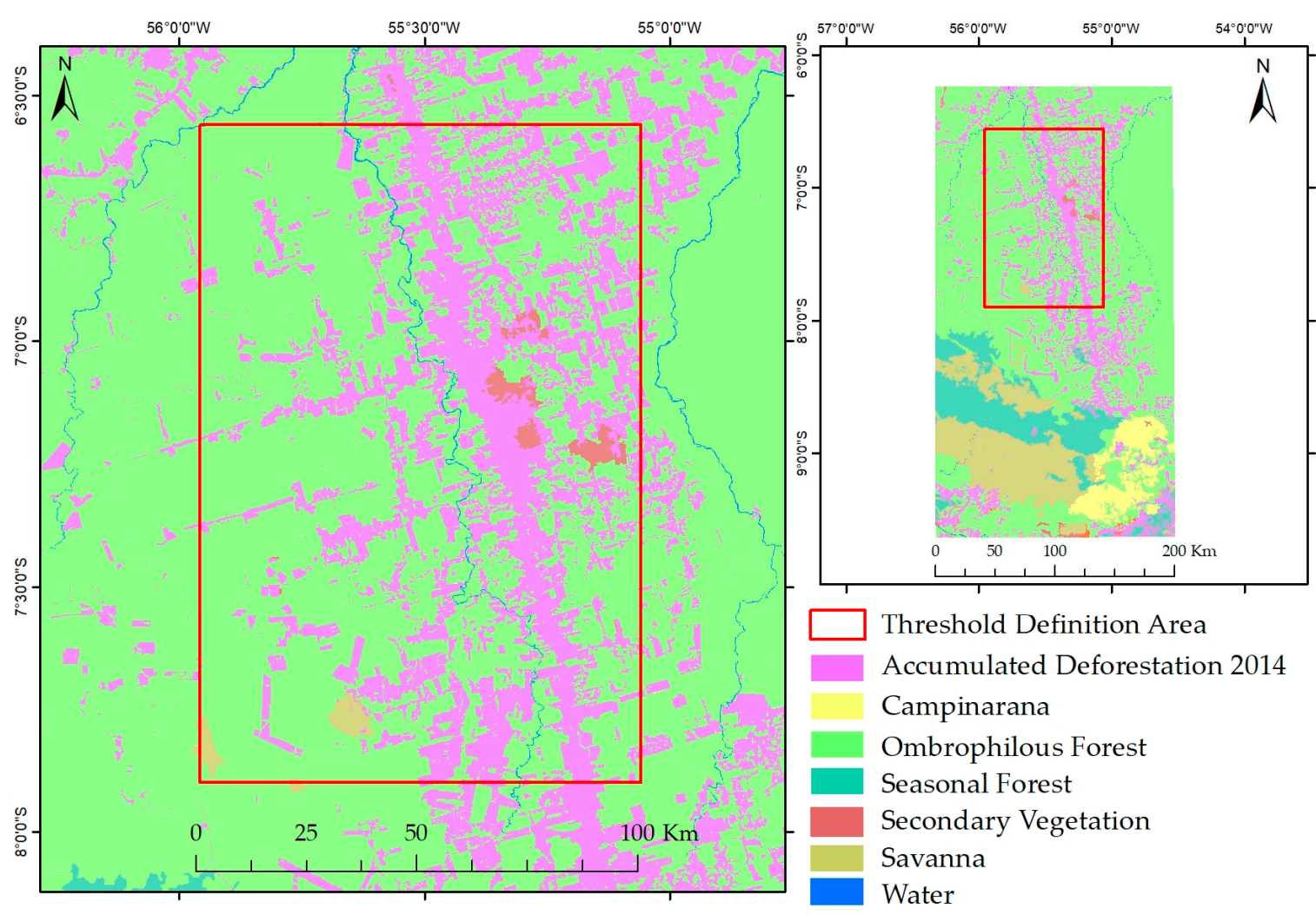

Figure 7. Area used to set the best threshold value.

We applied the average of the seven best thresholds in the complete time series of 14 years, generating a time series of burned area mask. The best threshold definition uses the equation $x \leq y$, where $\mathrm{x}$ is the value of the burned pixel and $\mathrm{y}$ is the threshold value for band 2, GEMI, NBR, NBR2, NDVI, $\triangle$ BAIM, and $\triangle$ MIRBI, while the equation $x \geq y$ for BAIM, MIRBI, $\triangle$ Band2, $\triangle$ GEMI, $\Delta$ NBR, $\triangle \mathrm{NBR} 2$, and $\triangle \mathrm{NDVI}$.

The overlap of the same-year polygons resulted in burned areas during the year. We used an algorithm that eliminated the burned areas that did not occur on at least two consecutive dates (8-day), which were considered noises because the ash of burns in savanna and forest requires a longer time to be extinguished $[69,87,88]$. The errors of areas burned in water bodies were corrected from the land use/land cover mapping produced by the Amazon Surveillance System (SIVAM) [55]. 


\subsection{Dataset Comparison and Accuracy Analysis}

Accuracy analysis used visual interpretations of independent areas of those adopted in the determination of optimal threshold values (Figure 8). The methodology assumed was proposed by Padilla et al. [89], which considers the confusion matrices between the classification of MODIS and Landsat images (Table 3) and its indices: Overall Accuracy (OA) (Equation (3)), Commission Errors (CE) (Equation (4)), and Omission Errors (OE) (Equation (5)) [90].

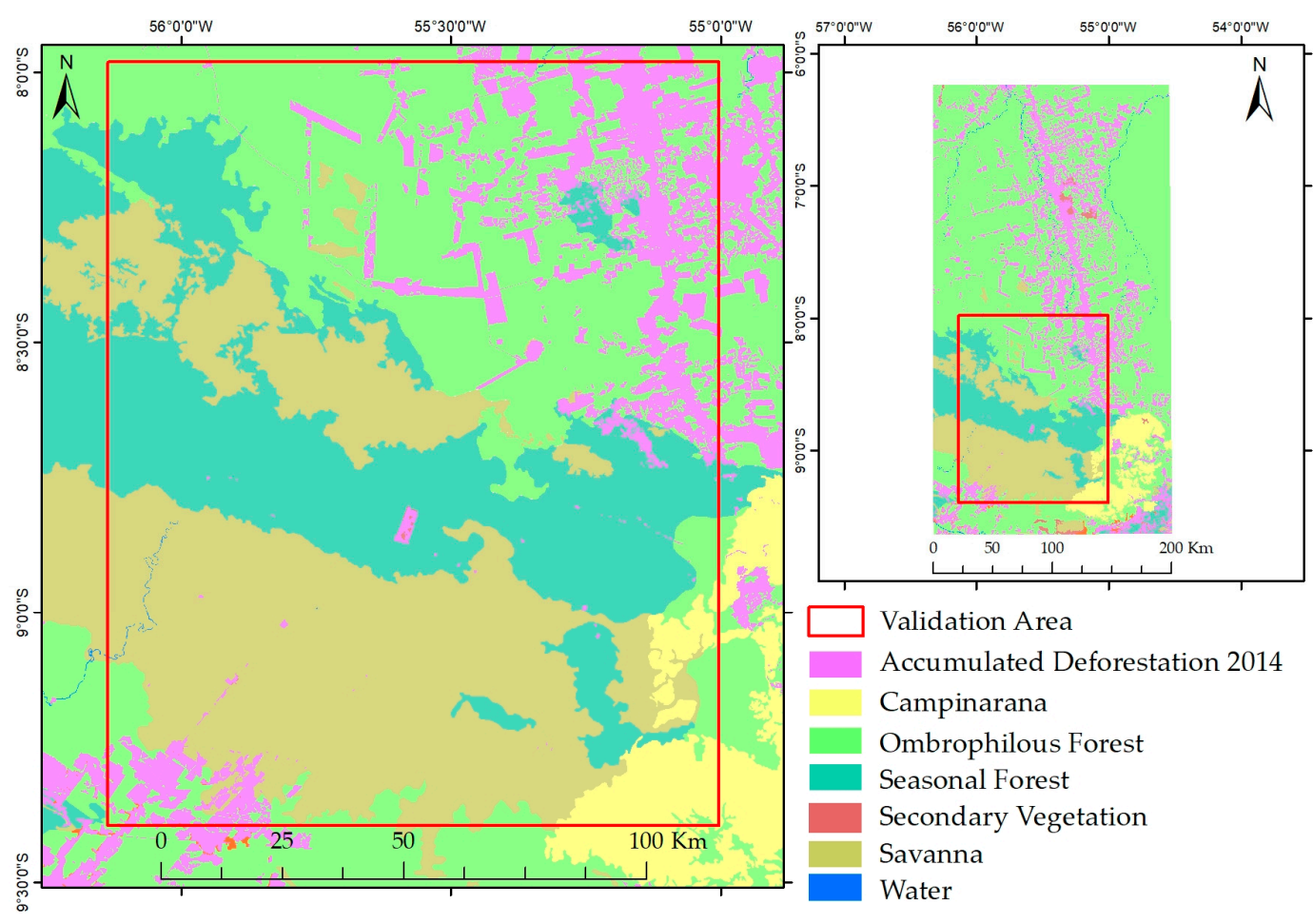

Figure 8. Reference map of the study area.

Table 3. Confusion matrix.

\begin{tabular}{|c|c|c|c|}
\hline & & \multicolumn{2}{|c|}{ True Condition (Landsat Classification) } \\
\hline & & Burned Area & Unburned Area \\
\hline $\begin{array}{l}\text { Predicted Condition } \\
\text { (MODIS Classification) }\end{array}$ & $\begin{array}{l}\text { Burned area } \\
\text { Unburned area }\end{array}$ & $\begin{array}{c}\text { True Positive (TP) } \\
\text { False Negative (FN) }\end{array}$ & $\begin{array}{l}\text { False Positive (FP) } \\
\text { True Negative (TN) }\end{array}$ \\
\hline
\end{tabular}

$$
\begin{gathered}
O A=\frac{\sum T P+\sum T N}{\text { Total Population }} * 100 \\
C E=\frac{\sum F P}{\sum F P+\sum T P} * 100 \\
O E=\frac{\sum F N}{\sum F N+\sum T P} * 100
\end{gathered}
$$

We also used the Dice coefficient (DC), described in Reference [91], which combines CE and OE into a single category according to the below Equation, as in Reference [38]:

$$
D C=\frac{2 * a}{2 * a+b+c}
$$

where " $a$ " refers to the burned area mapped correctly in both methods, " $b$ " the commission errors, and " $c$ " the omission errors. Given DC is a measure of aggregate precision, it obscures differences in the 
individual measurements of $\mathrm{CE}$ and $\mathrm{OE}$. Therefore, $\mathrm{CB}$ has limitations if $\mathrm{CE}$ and $\mathrm{OE}$ are not equally significant, in which case the accuracy analysis should be directed to the largest specific error [38].

The reference image corresponded to about $25 \%$ of the study area $\left(19,486.3664 \mathrm{~km}^{2}\right)$ obtained from the visual interpretation of TM, ETM+, and OLI images on the following dates: 10/10/2001, 10/05/2002, 09/22/2003, 10/02/2004, 09/19/2005, 09/22/2006, 09/09/2007, 09/27/2008, 09/30/2009, 09/09/2010, 09/12/2011,09/30/2012, 10/03/2013, and 09/28/2014. In 2012, we used Landsat 7 ETM+ images (even with the presence of errors) because it was the only sensor in operation of the Landsat program [92], the scan-line issues were masked and disregarded in that year's accuracy analysis.

The non-parametric McNemar's test [93] assessed the independence of the results obtained by pair-wise comparisons of the classifications [94]. The McNemar test calculates the chi-square distribution $\left(\mathrm{x}^{2}\right)$ considering the matrix elements of Table 4 in the following Equation:

$$
x^{2}=\frac{\left(f_{12}-f_{21}\right)^{2}}{f_{12}+f_{21}}
$$

Table 4. McNemar test between two classifications.

\begin{tabular}{cccc}
\hline & \multicolumn{3}{c}{ Classification 2 } \\
\cline { 2 - 4 } & Correct & Incorrect & Total \\
\hline Classification 1 & & & $\mathrm{f}_{11}+\mathrm{f}_{12}$ \\
\hline Correct & $\mathrm{f}_{11}$ & $\mathrm{f}_{12}$ & $\mathrm{f}_{21}+\mathrm{f}_{22}$ \\
\hline Incorrect & $\mathrm{f}_{21}$ & $\mathrm{f}_{22}$ & $\mathrm{f}_{11}+\mathrm{f}_{12}+\mathrm{f}_{21}+\mathrm{f}_{22}$ \\
\hline Total & $\mathrm{f}_{11}+\mathrm{f}_{21}$ & $\mathrm{f}_{12}+\mathrm{f}_{22}$ &
\end{tabular}

The McNemar test analysis considered 4000 random samples for each year between 2001 and 2014. The significance assessment compared the value of $x^{2}$ obtained with the tabulated value, indicating the null hypothesis when the $x^{2}$ value was less than $5 \%$ of significance (3.841), or rejection of the null hypothesis when the $\mathrm{x}^{2}$ value was higher.

The validation of the MCD45 [36], MCD64 [26], and Fire CCI [62,63] products used the same data set to facilitate comparison with the proposed methodologies. The MCD45 uses an algorithm that identifies burned areas daily, eliminating false events such as cloud shadows. The MCD64 identifies persistent changes in the time series of vegetation indices and includes the localization of active fire to define boundary values for the burned area and unburned area. The Fire CCI product combines active fire pixel information and spectral changes of the MERIS sensor time series. These products are available in monthly data with $500 \mathrm{~m}$ of resolution, where each pixel can indicate the exact day of the burn on Julian days (1-365), unburned area, cloud area, or water area [31,62].

\subsection{Analysis of the Spatial Relationships between Land Use/Land Cover Classes and Burned Area}

Land use dynamics is a crucial factor to understand the spatial pattern of fires. In this spatial analysis, we used the land use/land cover mapping produced by the Amazon Surveillance System (SIVAM) [55] and deforestation provided by the National Institute for Space Research by Project for Monitoring Deforestation in the Legal Amazon (PRODES) [54]. In the SIVAM mapping, land use/land cover classes considered those established by the Brazilian Institute of Geography and Statistics [55]: Ombrophylous Forests, Seasonal Forests, Campinarana, Savanna, Secondary Vegetation, Annual Deforestation, and Water. As the PRODES methodology considers one year beginning in August, we used Landsat images to update deforestation by the end of each year from 2001 to 2014, resulting in annual land cover maps. The intersection of information allowed us to evaluate the interactions between deforestation, land use, and fire. Moreover, we assessed the influence of the BR 163 highway on the occurrence of fires, calculating the percentage of burned area in a buffer zone with distance intervals of $20 \mathrm{~km}$ from the highway. 


\section{Results}

\subsection{Determination of the Best Threshold Value}

The use of both the seasonal differencing and the zero-mean normalization improves the overall accuracy of the original images (Table 5). The zero-mean normalization obtained better precision results (overall accuracy) than the Z-score normalization (increasing false positives) and seasonal differencing (lower overall accuracy).

The BAIM presented the best accuracy index from the original data and the difference index (Table 5). The normalized NIR band by Z-score or by the mean presented the best fit for the burn area detection, with higher overall accuracy values than all the spectral indices evaluated. The BAIM, NIR band, GEMI, and MIRBI normalized by the mean had similar overall accuracy, while the NBR and its variation NBR2 presented the fifth-best performance, despite being a widely-used index for the mapping of burned areas. The NDVI showed the worst value for overall accuracy.

The annual difference already implies the loss of one year of the time series [83]. Moreover, the use of fixed intervals without the image selection by quality causes the reduction of the validation area due to the presence of clouds in the differenced images (Table 2). Although the seasonal differences highlight the burned areas, there is confusion between newly cleared areas with or without burning and omission of pixels burned in consecutive years.

Table 5. Average of best thresholds and overall accuracy (OA) for different tested procedures in the years of 2001, 2002, 2004, 2005, 2008, and 2010.

\begin{tabular}{|c|c|c|c|c|c|c|c|}
\hline \multicolumn{8}{|c|}{ Original Data } \\
\hline & BAIM & Band 2 & GEMI & MIRBI & NBR & NBR2 & NDVI \\
\hline Threshold & 17.48 & 0.206 & 0.560 & 1.312 & 0.148 & 0.230 & 0.480 \\
\hline $\mathrm{OA}$ & $97.1 \%$ & $97.0 \%$ & $97.0 \%$ & $97.0 \%$ & $96.3 \%$ & $96.7 \%$ & $96.0 \%$ \\
\hline \multicolumn{8}{|c|}{ Seasonal Difference ( $\Delta=$ Pre-fire - Post-fire $)$} \\
\hline & $\triangle \mathrm{BAIM}$ & $\Delta$ Band 2 & $\triangle$ GEMI & $\triangle \mathrm{MIRBI}$ & $\triangle \mathrm{NBR}$ & $\triangle \mathrm{NBR} 2$ & $\triangle \mathrm{NDVI}$ \\
\hline Threshold & -31.2 & 0.04 & 0.11 & -0.25 & 0.22 & 0.12 & 0.22 \\
\hline OA & $98.7 \%$ & $98.2 \%$ & $98.3 \%$ & $98 \%$ & $98.2 \%$ & $98.4 \%$ & $98.3 \%$ \\
\hline \multicolumn{8}{|c|}{ Seasonal Difference ( $\Delta$ = Pre-fire - Post-fire) with selected images by quality next to birthday } \\
\hline & $\triangle \mathrm{BAIM}$ & $\Delta$ Band 2 & $\Delta \mathrm{GEMI}$ & $\triangle \mathrm{MIRBI}$ & $\triangle \mathrm{NBR}$ & $\triangle \mathrm{NBR} 2$ & $\Delta \mathrm{NDVI}$ \\
\hline Threshold & -28.32 & 0.041 & 0.156 & -0.406 & 0.278 & 0.138 & 0.172 \\
\hline $\mathrm{OA}$ & $97.2 \%$ & $97.1 \%$ & $97.0 \%$ & $97.0 \%$ & $96.7 \%$ & $96.5 \%$ & $96.5 \%$ \\
\hline \multicolumn{8}{|c|}{ Z-score normalization } \\
\hline & BAIM & Band 2 & GEMI & MIRBI & NBR & NBR2 & NDVI \\
\hline Threshold & 1.235 & -1.744 & -1.825 & 1.430 & -1.925 & -1.428 & -1.918 \\
\hline OA & $97.1 \%$ & $97.4 \%$ & $97.2 \%$ & $97.0 \%$ & $96.5 \%$ & $96.5 \%$ & $96.0 \%$ \\
\hline \multicolumn{8}{|c|}{ Zero-mean normalization } \\
\hline & BAIM & Band 2 & GEMI & MIRBI & NBR & NBR2 & NDVI \\
\hline Threshold & 11 & -0.109 & -0.200 & 0.250 & -0.284 & -0.160 & -0.203 \\
\hline $\mathrm{OA}$ & $97.8 \%$ & $97.9 \%$ & $97.7 \%$ & $97.3 \%$ & $96.9 \%$ & $96.9 \%$ & $96.8 \%$ \\
\hline
\end{tabular}

The lower accuracy of the seasonal difference method compared to the normalization method was due to the following factors: (a) Pixel quality, recurrent fires, and continuous deforestation. Pixel quality is one of the main limitations of seasonal difference in the tropical region due to intense cloud cover. The selection of high-quality pixels in two consecutive years is unlikely in most of the 
Amazon region, requiring algorithms for the selection of images close to the anniversary or temporal composition methods. In contrast, the normalization method does not depend on pixel quality in consecutive years, since it uses the entire time series available, facilitating the delimitation of fires in regions with high cloud presence.

The seasonal difference in areas with high fire recurrence tends to omit burned areas in consecutive years or regenerating regions due to the decrease in the difference values (Figure 9). The continuous deforestation of the tropical regions generates areas burned in new deforestation with different values of the fires in old deforestation, preventing the use of a single threshold value. Differently, the normalization method allows the grouping of burned areas in new and old deforestation from only one threshold value.

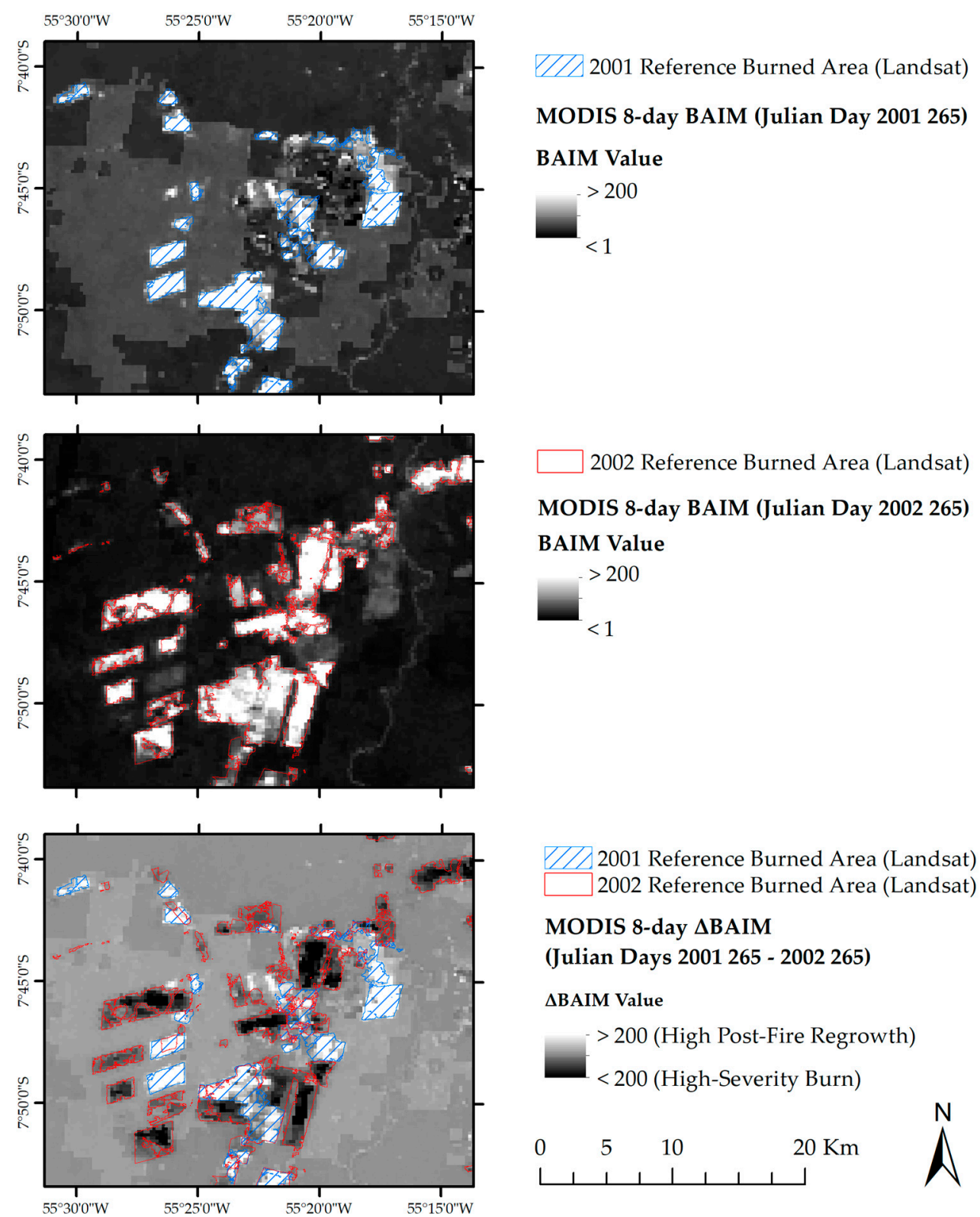

Figure 9. Comparison of the burned area vector detected by visual interpretation from Landsat images and the response of the Burnt Area Index (BAIM) and $\triangle$ BAIM indices in the MODIS images.

Figure 10 compares the application zero-mean normalization and the seasonal difference in the BAIM image. The RGB composition of the 2005 and 2006 dates (R-2005/G-2006/B-2005) highlights the changes between the two methods. The RGB combination of zero-mean images showed deforested 
areas of 2006 in magenta color, burned deforestation areas in white, with burned areas in old deforestation in green (Figure 10a). In this case, a single threshold identifies most of the fires in the white and green areas. The seasonal difference method has inverse values in relation to the zero-mean normalization method, where deforested areas in 2005 are in greens and "burned areas" in 2006 are in magenta (Figure 10b). However, burned deforestation areas also have green tones, mixing with deforested areas and preventing their separation by a single threshold.

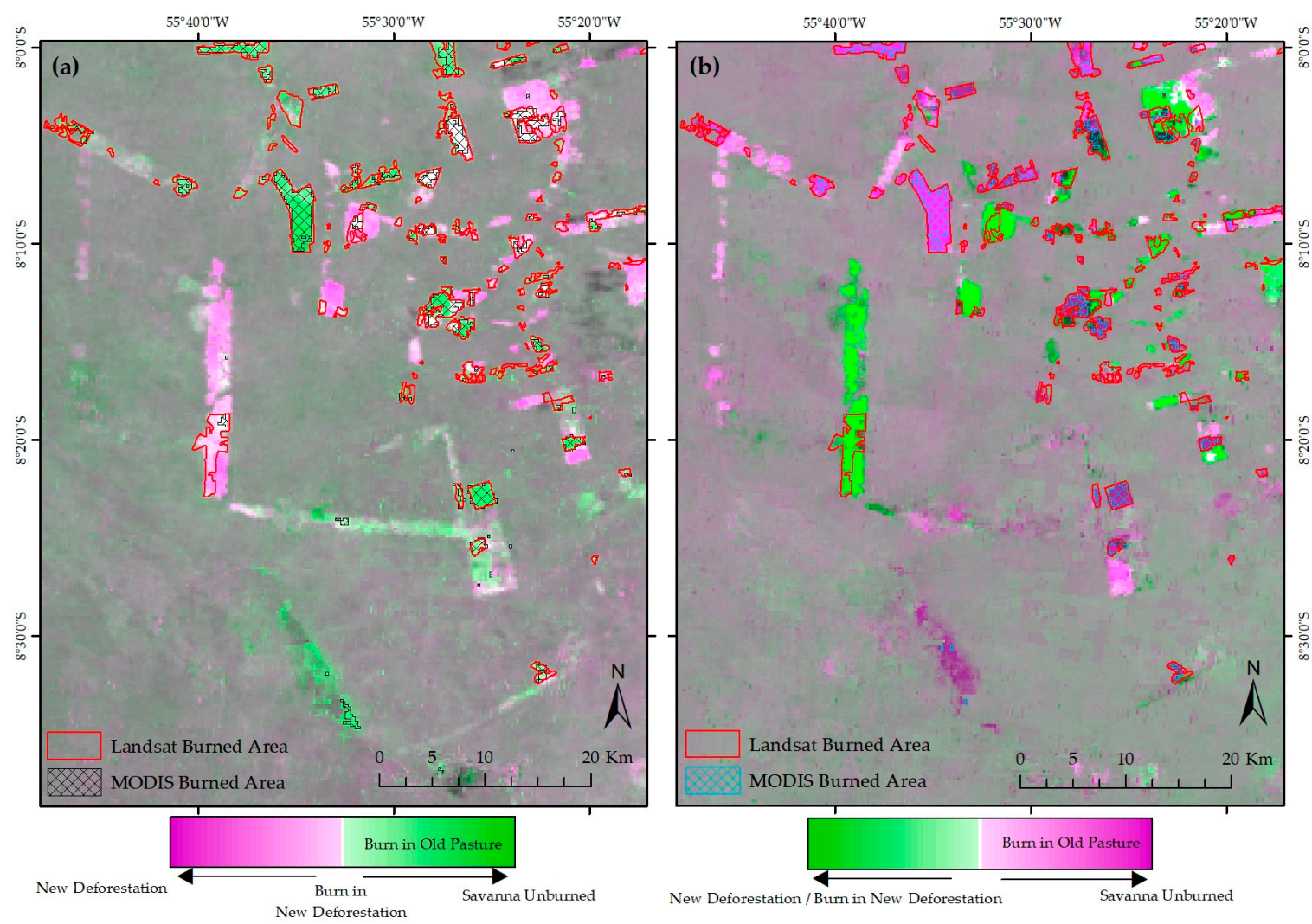

Figure 10. Detection of burned areas in the years 2005 and 2006 using: (a) BAIM with zero-mean normalization; and (b) $\triangle$ BAIM. Comparison of the burned areas extracted by visual interpretation of the Landsat images and by the automated method in the MODIS images.

\subsection{Validation and Data Comparison}

The MODIS mapping validation indicated that the NIR band normalized by the mean achieved the best result (Dice coefficient of 0.647) (Table 6). The zero-mean normalization obtained higher accuracy than the other methods in most of the tests performed. Z-Score normalization presented a significant improvement in the detection of burned areas in Band 2, GEMI, and MIRBI. The seasonal differencing with image selection by quality next to birthday improved the classification of all indexes, exhibiting better performance than the Z-Score normalization in the BAIM, GEMI, NBR, NBR2, and NDVI indices, and higher than the zero-mean normalization for the NBR index. The seasonal differencing using image selection showed the lowest commission error rate, and with the zero-mean normalization or Z-score had the smallest error of omission. 
Table 6. Accuracy indices of the burned areas using MODIS times series in the study area. "DC" is the Dice coefficient and "OA" is the overall accuracy.

\begin{tabular}{|c|c|c|c|c|c|c|c|}
\hline \multicolumn{8}{|c|}{ Original Data } \\
\hline & BAIM & Band 2 & GEMI & MIRBI & NBR & NBR2 & NDVI \\
\hline DC & 0.588 & 0.527 & 0.337 & 0.326 & 0.422 & 0.430 & 0.399 \\
\hline OA & $98.56 \%$ & $98.71 \%$ & $98.36 \%$ & $98.31 \%$ & $98.30 \%$ & $97.71 \%$ & $96.81 \%$ \\
\hline Commission Errors & $48.02 \%$ & $34.21 \%$ & $20.75 \%$ & $27.44 \%$ & $34.40 \%$ & $61.99 \%$ & $46.06 \%$ \\
\hline Omission Errors & $38.20 \%$ & $53.75 \%$ & $79.96 \%$ & $76.95 \%$ & $62.60 \%$ & $45.49 \%$ & $38.02 \%$ \\
\hline \multicolumn{8}{|c|}{ Seasonal Difference (Pre-fire - Post-fire) with fixed interval } \\
\hline & $\triangle \mathrm{BAIM}$ & $\Delta$ Band 2 & $\triangle \mathrm{GEMI}$ & $\triangle \mathrm{MIRBI}$ & $\triangle \mathrm{NBR}$ & $\triangle \mathrm{NBR} 2$ & $\Delta \mathrm{NDVI}$ \\
\hline DC & 0.506 & 0.485 & 0.384 & 0.334 & 0.428 & 0.412 & 0.400 \\
\hline OA & $98.15 \%$ & $97.87 \%$ & $97.11 \%$ & $96.59 \%$ & $97.51 \%$ & $97.50 \%$ & $97.15 \%$ \\
\hline Commission Errors & $29.82 \%$ & $71.67 \%$ & $40.71 \%$ & 42. $37 \%$ & $51.22 \%$ & $54.21 \%$ & $69.47 \%$ \\
\hline Omission Errors & $62.60 \%$ & $42.85 \%$ & 73. $57 \%$ & $74.02 \%$ & $61.23 \%$ & $62.01 \%$ & $59.41 \%$ \\
\hline \multicolumn{8}{|c|}{ Seasonal Difference (Pre-fire - Post-fire) with selected images } \\
\hline & $\triangle \mathrm{BAIM}$ & $\Delta$ Band 2 & $\triangle \mathrm{GEMI}$ & $\triangle \mathrm{MIRBI}$ & $\triangle \mathrm{NBR}$ & $\triangle \mathrm{NBR} 2$ & $\Delta \mathrm{NDVI}$ \\
\hline DC & 0.592 & 0.606 & 0.481 & 0.357 & 0.537 & 0.487 & 0.425 \\
\hline OA & $98.69 \%$ & $98.74 \%$ & $98.57 \%$ & $98.49 \%$ & $98.62 \%$ & $98.52 \%$ & $97.23 \%$ \\
\hline Commission Errors & $14.86 \%$ & $32.30 \%$ & $17.98 \%$ & $25.56 \%$ & $23.14 \%$ & $35.46 \%$ & $40.22 \%$ \\
\hline Omission Errors & $48.43 \%$ & $38.71 \%$ & $64.98 \%$ & $76.45 \%$ & $57.50 \%$ & $58.50 \%$ & $46.72 \%$ \\
\hline \multicolumn{8}{|c|}{ Z-score normalization } \\
\hline & BAIM & Band 2 & GEMI & MIRBI & NBR & NBR2 & NDVI \\
\hline $\mathrm{DC}$ & 0.591 & 0.618 & 0.476 & 0.501 & 0.429 & 0.452 & 0.397 \\
\hline OA & $98.38 \%$ & $98.80 \%$ & $98.54 \%$ & $98.44 \%$ & $98.69 \%$ & $97.73 \%$ & $96.38 \%$ \\
\hline Commission Errors & $45.42 \%$ & $38.97 \%$ & $34.16 \%$ & $35.80 \%$ & $45.77 \%$ & $47.23 \%$ & $56.81 \%$ \\
\hline Omission Errors & $39.36 \%$ & $38.70 \%$ & $62.58 \%$ & $55.90 \%$ & $45.45 \%$ & $45.74 \%$ & $45.59 \%$ \\
\hline \multicolumn{8}{|c|}{ Zero-mean normalization } \\
\hline & BAIM & Band 2 & GEMI & MIRBI & NBR & NBR2 & NDVI \\
\hline $\mathrm{DC}$ & 0.625 & 0.647 & 0.566 & 0.539 & 0.508 & 0.503 & 0.479 \\
\hline $\mathrm{OA}$ & $98.36 \%$ & $98.99 \%$ & $98.44 \%$ & $98.59 \%$ & $98.66 \%$ & $98.31 \%$ & $97.54 \%$ \\
\hline Commission Errors & $38.01 \%$ & $32.41 \%$ & $28.29 \%$ & $33.21 \%$ & $35.55 \%$ & $46.61 \%$ & $48.60 \%$ \\
\hline Omission Errors & $31.64 \%$ & $34.75 \%$ & $55.20 \%$ & $49.60 \%$ & $42.69 \%$ & $42.48 \%$ & $30.96 \%$ \\
\hline
\end{tabular}

The McNemar test confirmed the statistical independence between most of the classification methods, presenting values of $x^{2}>3.841$ (Figure 11). The most accurate method (Band 2 with zero-mean normalization) was statistically different from the other classifications. The procedures with the highest degree of agreement between them were those derived from the GEMI, MIRBI, and NBR2 indices, while the methods based on Band 2, BAIM, and Seasonal Difference were independent.

Considering the same reference data (Landsat-TM, ETM +, and OLI Images), the burned area products (MCD45, MCD65, and FIRE CCI) presented less than 25\% of commission errors, like the seasonal difference method, but due to the high error rate of omission, the Dice coefficient was lower than all the methods used. The MCD45 and FIRE CCI products had a Dice coefficient lower than 0.11 and omission errors higher than $90 \%$. The MCD64 product obtained the Dice coefficient of 0.24 in detriment of the reduction of the omission errors, surpassing the products MCD45 and FIRE_CCI (Table 7). The MODIS products still need improvements [24], validations in Africa using Landsat images obtained $34 \%$ commission errors and 59\% omission errors [86], and globally containing a commission error of $46 \%$ and omission error of $72 \%$, where specific biomass showed more satisfactory results than others such as Borealis Forestry and Tropical and subtropical Savanna [38]. The imprecision 
of the proposed method occurred in small burn areas due to the spatial resolution difference between the sensors used for validation, showing commission errors in forest and savanna areas. The proposed method had a lower commission error rate than MODIS / MERIS products, which focused on the resolution difference with the validation image (Figure 12).

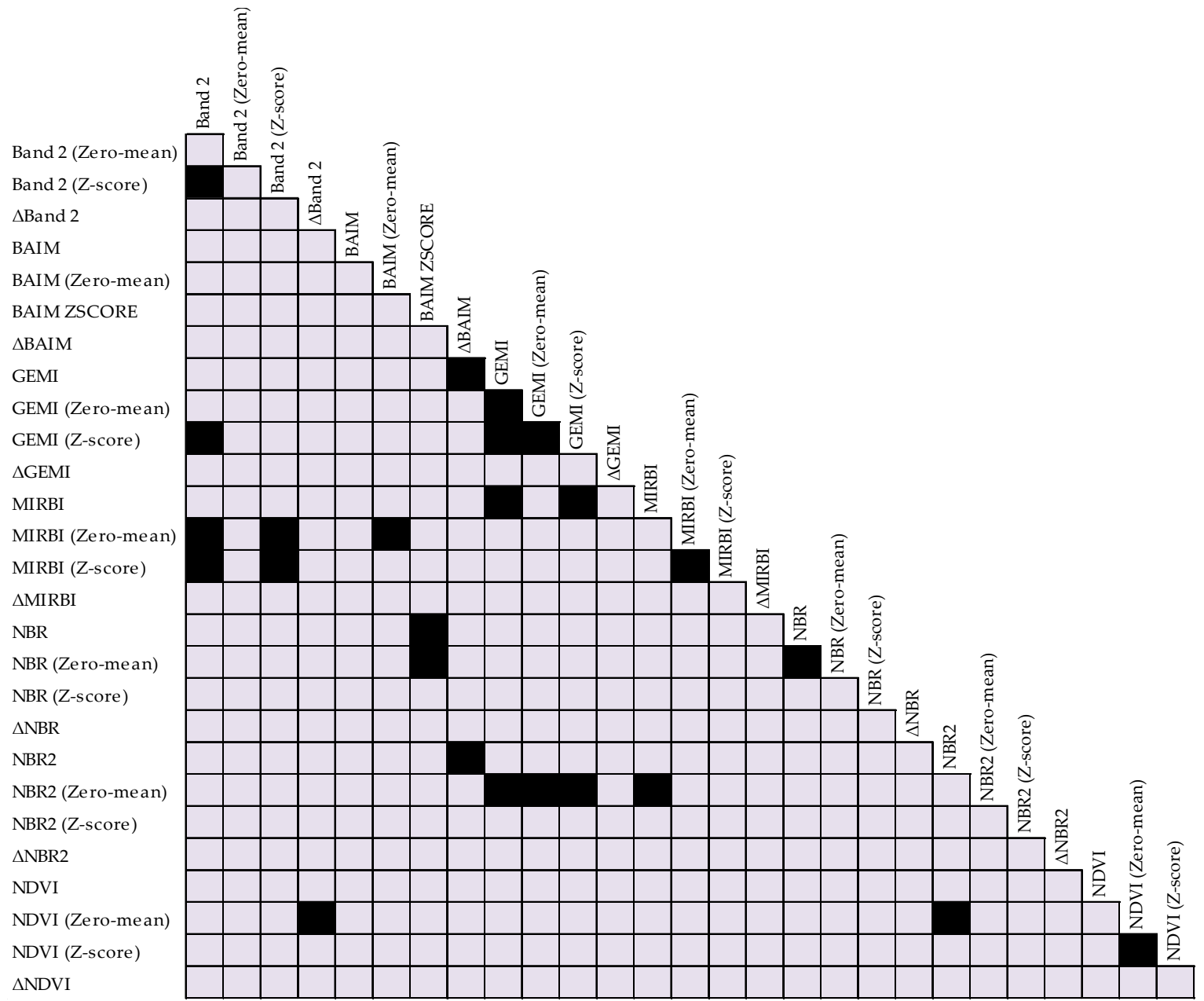

Figure 11. McNemar's test from the original image and the methods of normalization (zero-mean and Z-score) and seasonal differencing (selected images). The black markings indicate the statistical equivalence of the two methods with chi-square $<3.841$.

Table 7. Dice coefficient and overall accuracy of the burned areas for MCD45/MCD64/FIRE CCI data in the study area during 2001-2014 period.

\begin{tabular}{ccccc}
\hline Burned Area Product & Overall Accuracy & Dice Coefficient & Commission Errors & Omission Errors \\
\hline MCD45 & $98.58 \%$ & 0.11 & $24.34 \%$ & $93.55 \%$ \\
MCD64 & $98.61 \%$ & 0.24 & $23.83 \%$ & $84.51 \%$ \\
FIRE_CCI & $98.48 \%$ & 0.09 & $24.89 \%$ & $94.67 \%$ \\
\hline
\end{tabular}




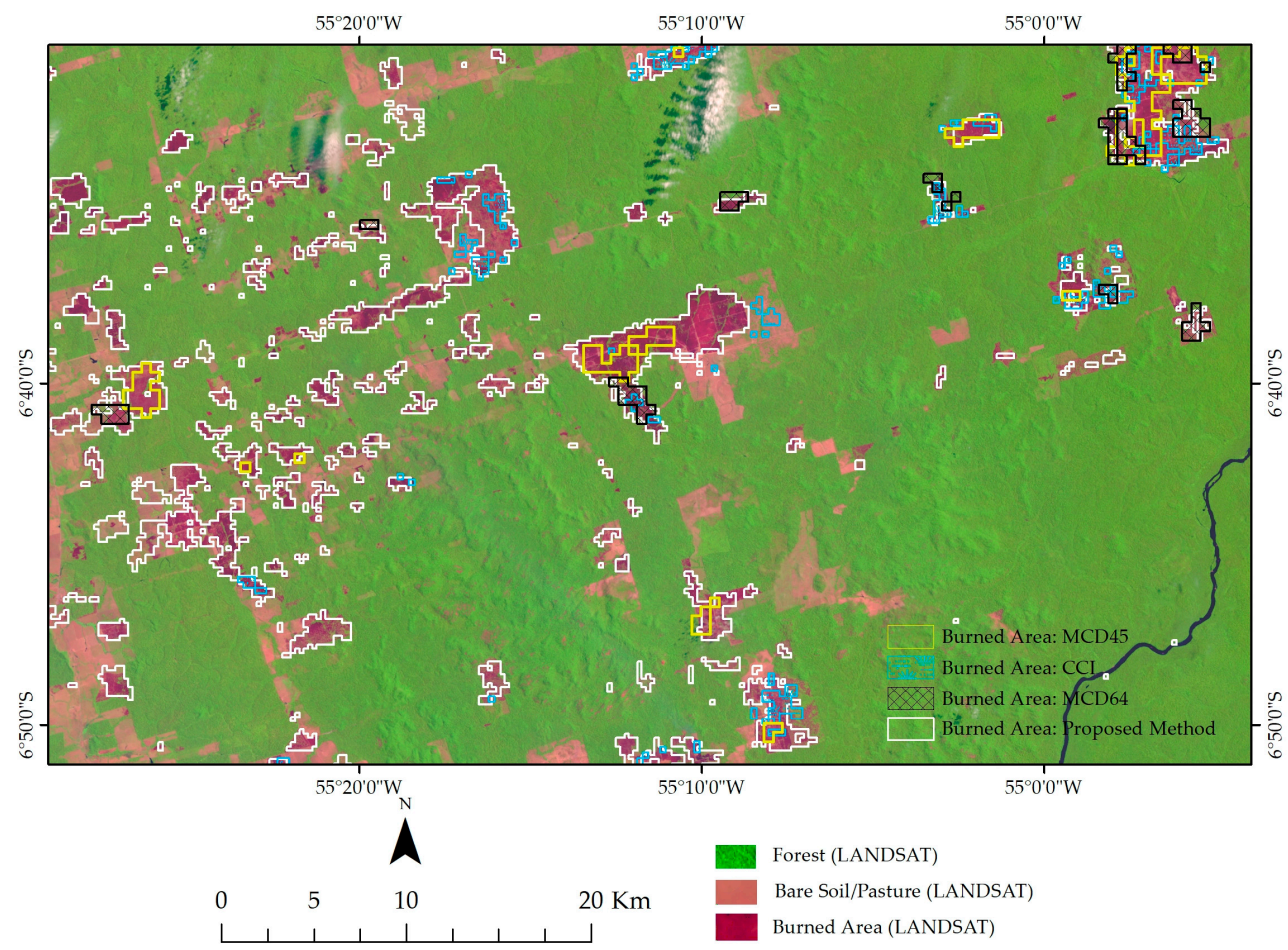

Figure 12. Comparison of burned area mappings from the proposed method, MCD45, MCD64, and FIRE CCI products and Landsat TM image.

\subsection{Mapping Validation by Land Cover Type}

The accuracy analysis of the burned area mapping by different land cover used the result of higher accuracy (NIR band and zero-mean normalization). The overall accuracy was higher than $98 \%$ in all classes, due to the high proportion of unburned area correctly identified. The Campinarana and Deforestation classes presented the highest Dice coefficients ( 0.778 and 0.755 , respectively), and lower commission and omission errors. Burnings in the Ombrophilous Forest obtained low commission errors, but significant errors of omission. Burnings in savanna vegetation and seasonal forests presented the highest rates of commission and omission errors, respectively (Table 8).

Table 8. Estimated accuracy of burned area for each land use/cover classes. The water and secondary vegetation were not evaluated by the low level of representation of fires in the selected area.

\begin{tabular}{ccccc}
\hline Land Cover & Overall Accuracy & Dice Coefficient & Commission Errors & Omission Errors \\
\hline Campinarana & $99.25 \%$ & 0.778 & $9.71 \%$ & $27.60 \%$ \\
Deforestation/Pasture & $99.19 \%$ & 0.755 & $18.57 \%$ & $34.76 \%$ \\
Ombrophilous Forest & $98.68 \%$ & 0.506 & $23.40 \%$ & $49.62 \%$ \\
Savanna & $98.62 \%$ & 0.466 & $59.25 \%$ & $37.42 \%$ \\
Seasonal Forest & $98.57 \%$ & 0.371 & $23.23 \%$ & $76.85 \%$ \\
\hline
\end{tabular}

\subsection{Land Use/Land Cover Classes and Burned Area Patterns}

Fire events and deforestation showed a high correlation (Table 9). Deforestation had the highest fire representativeness in the years studied, representing more than $70 \%$ of the total area burned annually. This attested to the anthropogenic influence on current burning patterns, both in deforestation and in agricultural management. In the study area, the Ombrophylous Forest had intense deforestation, decreasing from $70 \%$ in 2000 to $59 \%$ in 2014, which resulted in a high number of burnings in the years 2004,2006 , and 2010. More than $16 \%$ of deforested areas burned in 2004, while less than $2 \%$ burned in 2013. The other types of vegetation (Savanna, Seasonal Forests, and Secondary Vegetation) presented a low proportion of annual burned area, with average values smaller than $1 \%$ of the affected areas. 
Table 9. Annual burned area $\left(\mathrm{km}^{2}\right.$ and percentage within each class) from MODIS daily images for the following classes of land use and land cover: Campinarana (CP), Deforestation/Pasture (D/P), Ombrophilous Forest (OF), Savanna (S), Seasonal Forest (SF), and Secondary Vegetation (SV).

\begin{tabular}{|c|c|c|c|c|c|c|}
\hline \multicolumn{7}{|c|}{ Area $\left(\mathbf{k m}^{2}\right)$} \\
\hline Year & $\mathrm{CP}$ & $\mathrm{D} / \mathrm{P}$ & OF & $S$ & SF & SV \\
\hline 2001 & $\begin{array}{l}14.16 \\
(0.5 \%)\end{array}$ & $\begin{array}{l}280.66 \\
(6.9 \%)\end{array}$ & $\begin{array}{l}49.56 \\
(0.1 \%)\end{array}$ & $\begin{array}{c}2.55 \\
(0.03 \%)\end{array}$ & $\begin{array}{c}12.18 \\
(0.2 \%)\end{array}$ & $\begin{array}{c}0.28 \\
(0.1 \%)\end{array}$ \\
\hline 2002 & $\begin{array}{c}12.84 \\
(0.4 \%)\end{array}$ & $\begin{array}{c}773.68 \\
(14.4 \%)\end{array}$ & $\begin{array}{c}84.08 \\
(0.2 \%)\end{array}$ & $\begin{array}{c}14.61 \\
(0.18 \%)\end{array}$ & $\begin{array}{c}12.77 \\
(0.2 \%)\end{array}$ & $\begin{array}{c}0.78 \\
(0.2 \%)\end{array}$ \\
\hline 2003 & $\begin{array}{c}26.82 \\
(0.9 \%)\end{array}$ & $\begin{array}{l}497.05 \\
(8.2 \%)\end{array}$ & $\begin{array}{c}92.58 \\
(0.2 \%)\end{array}$ & $\begin{array}{c}9.06 \\
(0.11 \%)\end{array}$ & $\begin{array}{c}18.24 \\
(0.3 \%)\end{array}$ & $\begin{array}{c}1.05 \\
(0.3 \%)\end{array}$ \\
\hline 2004 & $\begin{array}{l}51.60 \\
(1.7 \%)\end{array}$ & $\begin{array}{l}1203.22 \\
(16.8 \%)\end{array}$ & $\begin{array}{l}235.74 \\
(0.5 \%)\end{array}$ & $\begin{array}{c}15.58 \\
(0.19 \%)\end{array}$ & $\begin{array}{c}20.14 \\
(0.3 \%)\end{array}$ & $\begin{array}{c}0.12 \\
(0.0 \%)\end{array}$ \\
\hline 2005 & $\begin{array}{c}33.10 \\
(1.1 \%)\end{array}$ & $\begin{array}{l}771.25 \\
(9.9 \%)\end{array}$ & $\begin{array}{l}111.60 \\
(0.2 \%)\end{array}$ & $\begin{array}{c}15.38 \\
(0.19 \%)\end{array}$ & $\begin{array}{c}23.97 \\
(0.4 \%)\end{array}$ & $\begin{array}{c}0.86 \\
(0.3 \%)\end{array}$ \\
\hline 2006 & $\begin{array}{c}26.85 \\
(0.9 \%)\end{array}$ & $\begin{array}{l}781.16 \\
(9.4 \%)\end{array}$ & $\begin{array}{l}244.92 \\
(0.5 \%)\end{array}$ & $\begin{array}{c}22.15 \\
(0.28 \%)\end{array}$ & $\begin{array}{c}70.80 \\
(1.1 \%)\end{array}$ & $\begin{array}{c}1.52 \\
(0.5 \%)\end{array}$ \\
\hline 2007 & $\begin{array}{c}18.24 \\
(0.6 \%)\end{array}$ & $\begin{array}{l}677.03 \\
(7.6 \%)\end{array}$ & $\begin{array}{l}143.28 \\
(0.3 \%)\end{array}$ & $\begin{array}{c}5.21 \\
(0.06 \%)\end{array}$ & $\begin{array}{c}22.24 \\
(0.3 \%)\end{array}$ & $\begin{array}{c}0.20 \\
(0.1 \%)\end{array}$ \\
\hline 2008 & $\begin{array}{c}41.48 \\
(1.4 \%)\end{array}$ & $\begin{array}{l}625.33 \\
(6.6 \%)\end{array}$ & $\begin{array}{l}130.02 \\
(0.3 \%)\end{array}$ & $\begin{array}{c}28.77 \\
(0.36 \%)\end{array}$ & $\begin{array}{c}44.52 \\
(0.7 \%)\end{array}$ & $\begin{array}{c}1.37 \\
(0.4 \%)\end{array}$ \\
\hline 2009 & $\begin{array}{c}15.19 \\
(0.5 \%)\end{array}$ & $\begin{array}{l}233.87 \\
(2.3 \%)\end{array}$ & $\begin{array}{l}121.21 \\
(0.3 \%)\end{array}$ & $\begin{array}{c}4.53 \\
(0.06 \%)\end{array}$ & $\begin{array}{c}52.62 \\
(0.8 \%)\end{array}$ & $\begin{array}{c}0.43 \\
(0.1 \%)\end{array}$ \\
\hline 2010 & $\begin{array}{c}7.21 \\
(0.2 \%)\end{array}$ & $\begin{array}{l}749.36 \\
(7.2 \%)\end{array}$ & $\begin{array}{l}196.83 \\
(0.4 \%)\end{array}$ & $\begin{array}{c}11.10 \\
(0.14 \%)\end{array}$ & $\begin{array}{c}23.60 \\
(0.4 \%)\end{array}$ & $\begin{array}{c}1.62 \\
(0.5 \%)\end{array}$ \\
\hline 2011 & $\begin{array}{c}23.66 \\
(0.8 \%)\end{array}$ & $\begin{array}{l}214.61 \\
(2.0 \%)\end{array}$ & $\begin{array}{c}90.71 \\
(0.2 \%)\end{array}$ & $\begin{array}{c}5.95 \\
(0.07 \%)\end{array}$ & $\begin{array}{c}15.54 \\
(0.2 \%)\end{array}$ & $\begin{array}{c}0.66 \\
(0.2 \%)\end{array}$ \\
\hline 2012 & $\begin{array}{c}4.49 \\
(0.1 \%)\end{array}$ & $\begin{array}{l}395.61 \\
(3.5 \%)\end{array}$ & $\begin{array}{c}87.07 \\
(0.2 \%)\end{array}$ & $\begin{array}{c}2.78 \\
(0.03 \%)\end{array}$ & $\begin{array}{c}13.08 \\
(0.2 \%)\end{array}$ & $\begin{array}{c}0.40 \\
(0.1 \%)\end{array}$ \\
\hline 2013 & $\begin{array}{c}10.77 \\
(0.4 \%)\end{array}$ & $\begin{array}{l}166.01 \\
(1.4 \%)\end{array}$ & $\begin{array}{c}47.75 \\
(0.1 \%)\end{array}$ & $\begin{array}{c}3.30 \\
(0.04 \%)\end{array}$ & $\begin{array}{c}6.06 \\
(0.1 \%)\end{array}$ & $\begin{array}{c}0.25 \\
(0.1 \%)\end{array}$ \\
\hline 2014 & $\begin{array}{c}5.65 \\
(0.2 \%)\end{array}$ & $\begin{array}{l}748.24 \\
(6.2 \%)\end{array}$ & $\begin{array}{l}102.40 \\
(0.2 \%)\end{array}$ & $\begin{array}{c}3.18 \\
(0.04 \%)\end{array}$ & $\begin{array}{c}16.60 \\
(0.3 \%)\end{array}$ & $\begin{array}{c}2.06 \\
(0.6 \%)\end{array}$ \\
\hline
\end{tabular}

The highest occurrence of burned areas was concentrated near the BR-163 highway, especially in the buffer zone up to $40 \mathrm{~km}$ (Table 10). More than $85 \%$ of the forest area showed no fires. In the 14 years examined, the burned area was slightly more than $11 \%$ of the study area (Figure 13). Most of the area burned only once or twice during the study period ( $7 \%$ and $3 \%$ ). Approximately $1 \%$ of the pixels burned in more than three years in the time series, concerning the agricultural areas. The indigenous territories and the military base showed a low incidence of fires in the temporal series, in contrast, the Jamanxim National Forest (highly degraded conservation unit) exhibited a high frequency of fires. The private or unlicensed properties (without the direct intervention of public authorities) totaled $24,358.8 \mathrm{~km}^{2}$ of the study area, and corresponded to the highest burning rates, followed by the settlement projects (Figure 13).

Table 10. Burned area percentage in buffer zones with $20 \mathrm{~km}$ distance intervals from the BR-163 highway.

\begin{tabular}{ccccccccc}
\hline Distance & $20 \mathrm{~km}$ & $40 \mathrm{~km}$ & $60 \mathrm{~km}$ & $80 \mathrm{~km}$ & $100 \mathrm{~km}$ & $120 \mathrm{~km}$ & $140 \mathrm{~km}$ & $160 \mathrm{~km}$ \\
\hline Burned Area (\%) & $12.5 \%$ & $10.1 \%$ & $3.7 \%$ & $1.6 \%$ & $0.9 \%$ & $2.7 \%$ & $2.5 \%$ & $0.7 \%$ \\
\hline
\end{tabular}




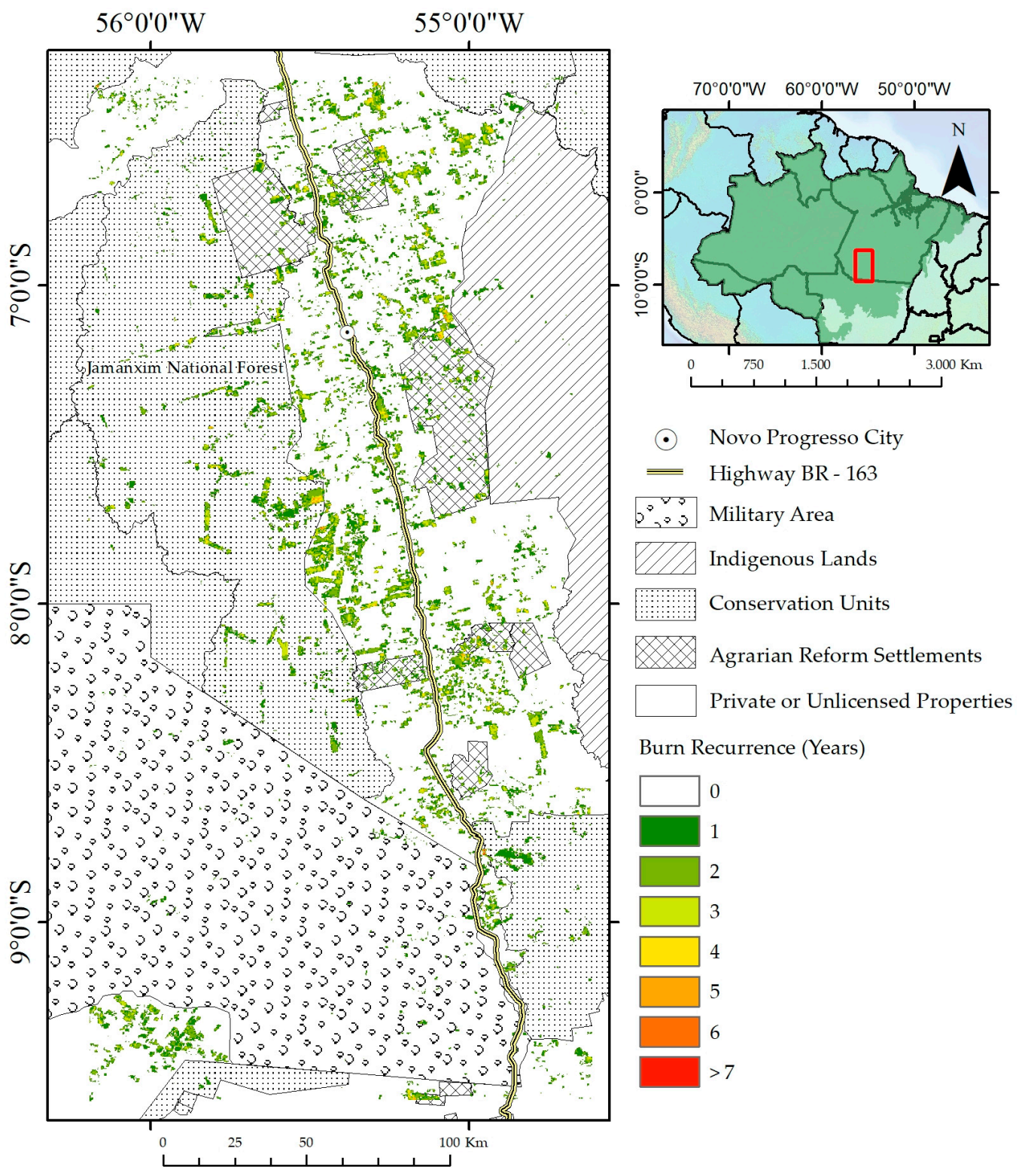

Figure 13. Map of the fire recurrence (14 Years).

\section{Discussion}

Consistent with other research, seasonal differences and standardization techniques improved the burned area mapping $[47,83,95]$. However, seasonal differencing considering continuous data in time has the following limitations [83]: (a) The subtraction operation highlights the noise present in the two images (pre- and post-fire); (b) Fire detection is susceptible to interference of phenological variations, oscillation of cropping cycles, and land use changes. Therefore, the main difficulty of the seasonal difference is to ensure that other changes independent of the fire event are not confused with burned areas, such as deforestation or atmospheric variations. The seasonal difference in continuous data over time intensifies this limitation, as opposed to the use of discrete data chosen by the analyst.

Another alternative is the use of time series standardized by pixel, which has been used to identify burned areas in the savanna region of Central Brazil [83]. This procedure converts the data set to Z-Score values (with the mean of zero and standard deviation of one), facilitating the determination of a threshold value of the burned areas from a reference image. This technique does not alter the relative values of the temporal signature and avoids the errors described by the seasonal difference. However, the application of this method to forest areas generated false positives mainly related to the presence 
of cloud shadows not detected by the MODIS sensor quality mask due to the resolution difference between the products. The MODIS cloud mask has a 1-km resolution, while the images of this research had 250- and 500-m resolutions. The time series of spectral indexes in forest areas shows low standard deviation in comparison to the other targets, always having a photosynthetically active behavior with little change over time. Therefore, the Z-score normalization that has the standard deviation as the denominator causes an overestimation of the normalized forest values, differently from what occurs in the vegetation with high seasonal variation such as the savannah. An alternative proposed in this research was the use of zero-mean normalization, with only the subtraction by the mean, without the division by the standard deviation. This normalization approach allowed an adaptation of the method [83] for these vegetation types, and more accurate results in the detection of burned areas. The main advantage of the zero-mean normalization is that it equalizes the values of the burned area in the different scenarios of the Amazon region (forest, pasture, and deforestation), facilitating their detection from the single threshold.

Except for the NBR index, all the data tested (band of Near Infrared, BAIM, GEMI, MIRBI, NBR2, and NDVI) presented better accuracy using zero-mean normalization than the other procedures (original image, seasonal differencing, seasonal differencing with the selected images, and Z-score), attesting to the superiority of the zero-mean in detriment of the z-score normalization for the mapping of burning areas in forest regions. The NBR index presents a higher accuracy using the seasonal difference with the selected images.

Within the normalization procedures, the input data that had the best Dice coefficient were two: (a) BAIM in the original image and seasonal difference with fixed interval; and (b) Infrared band in the seasonal differencing with selected images, Z-score, and zero-mean normalization methods. Therefore, the best result used the infrared band and zero-mean normalization. Pleniou et al. [96] and Alonso-Canas [63] emphasized the ability to separate the burned areas from the near infrared. Although the NBR and dNBR indices are widely used in the literature for the detection of burned areas and fire severity $[27,97]$, there are limitations in the study area due to the intense dynamics of deforestation. Roy et al. [97] warned about the ineffectiveness of the NBR index to measure the severity of burning in tropical forests.

Some limitations persist in the mapping of small areas burned due to MODIS spatial resolution, as verified by other authors [81,98]. The burned areas on small farms and agrarian reform settlements result in an underestimation of the total area burned. Moreover, the daily images may present better results than the MODIS products from the multitemporal compositing techniques [66,99]. Future research efforts could use high spatial and temporal resolution satellite data, which should reduce the omission of undetected small fires.

The comparison between the MCD45, MCD64, and FIRE CCI products and the reference burned area mapping demonstrated proved unfeasible for use in the Amazon region due to the low detection of burned areas. Libonati et al. [100] also highlighted a high percentage of omission errors in the MCD45 product. Even with MCD64 product enhancements, the omission errors may exceed 60\% [35]. Despite the limitations of the burned area products in the Amazon, these were developed for the world surpassing in many cases other techniques of burned-area detection. The spatial resolution of $500 \mathrm{~m}$ from MODIS and $300 \mathrm{~m}$ from FIRE CCI products influenced the difference between the two methods.

The methodology used presents better fire detection capacity in pasture/deforestation areas and Campinarana vegetation. Deforested regions were the most affected by fires, where it is used at regular intervals for pasture maintenance, combating invasive plants, pests, and improving low soil productivity [13]. The lack of access to alternative agricultural management is also an essential factor to explain the high rates of fires in the region [101]. Locations with a single occurrence of burning in the time series are often fires in the native forest that originated externally in agricultural areas and became out of control. In this context, fragmented forests are more vulnerable to fires because of the increased border with agrarian regions $[2,8]$. 
The Novo Progresso region is located between a conservation unit and Indigenous Parks that are essential barriers to deforestation and fires [7,102]. However, the Jamanxim National Forest is among the most deforested and burnt protected areas of the Brazilian Amazon due to the proximity of the Cuiabá-Santarém highway. Currently, the Brazilian Congress is negotiating a $26 \%$ reduction proposal in the Jamanxim National Forest area to allow the construction of a railroad for the transport of grain from Mato Grosso by the port of Miritituba, Pará. This railway will undoubtedly cause impacts increasing the occurrence of deforestation and fires.

Although the most widespread methods for detecting burned areas are based on specific thresholds of spectral indices, the temporal normalization per pixel should be evaluated in the future with other methods. Instead of considering spectral indices, several studies use spectral mixing techniques to highlight burned areas. $[85,103,104]$. Thus, the temporal normalization techniques for the pixel can be further tested in the time series of fraction images. Another approach used is the supervised classification, either by pixel or object-based, which depends on the collection of samples of the different targets present in the scene $[105,106]$. Thus, the supervised classification on normalized data per pixel should be tested.

\section{Conclusions}

This study evaluated different procedures for the mapping of burned areas in the Amazon Forest, considering different image processing in the MODIS time series, such as seasonal difference, normalization (Z-score, zero-mean normalization, and without normalization), spectral indices and bands (BAIM, GEMI, MIRBI, NBR, NBR2, NDVI, and NIR band). The zero-mean normalization and seasonal difference showed improvements in burned area detection in comparison with the original images. Although the seasonal difference method was widely used in other biomes, the zero-mean normalization achieved better accuracy, confirmed by the McNemar statistical test. The use of the NIR band presented the best results in burned area detection. The zero-mean normalization allowed comparison of the burning behaviors of different environments in an integrated way, defining a single threshold value for the different vegetal formations. This approach to time series normalization per pixel is an innovation in the processing of remotely sensed data for detection of burned areas that must be improved for other environments and monitoring studies. In addition to the methodology presented, greater accuracy in the detection of burned areas in Campinarana and pastures, burned areas occur predominantly in deforested areas, which account for more than $70 \%$ of annually burned areas. The adopted methodology presented an overall accuracy $(98.99 \%)$ greater than the burned area products (MCD45, MCD64, and FIRE CCI), and low errors of omission, despite having higher commission errors. The improvement of the monitoring of burned areas in the Amazon enables better environmental management and the estimations of their impacts.

Author Contributions: Conceptualization, N.C.S and O.A.C.J.; methodology, N.C.S. and O.A.C.J.; software, O.A.C.J.; validation, N.C.S. and O.A.C.J.; formal analysis, N.C.S., O.A.C.J., R.A.T.G and R.F.G.; writing-original draft preparation, N.C.S., O.A.C.J., R.A.T.G and R.F.G.; writing-review and editing, N.C.S., O.A.C.J., R.A.T.G and R.F.G.; supervision, O.A.C.J.

Funding: This research was funded by the Conselho Nacional de Desenvolvimento Científico e Tecnológico $(\mathrm{CNPq})$ and Cordenação de Aperfeiçoamento de Pessoal de Nível Superior (CAPES).

Acknowledgments: We thank the Cordenação de Aperfeiçoamento de Pessoal de Nível Superior (CAPES) for the Doctoral's scholarship grant.

Conflicts of Interest: The authors declare no conflict of interest. 


\section{References}

1. Morton, D.C.; Defries, R.S.; Randerson, J.T.; Giglio, L.; Schroeder, W.; van der Werf, G.R. Agricultural intensification increases deforestation fire activity in Amazonia. Glob. Chang. Biol. 2008, 14, 2262-2275. [CrossRef]

2. Cochrane, M.A. Synergistic interactions between habitat fragmentation and fire in evergreen tropical forests. Conserv. Biol. 2001, 15, 1515-1521. [CrossRef]

3. Pivello, V.R. The use of fire in the cerrado and Amazonian rainforests of Brazil: Past and present. Fire Ecol. 2011, 7, 24-39. [CrossRef]

4. Silvestrini, R.A.; Soares-Filho, B.S.; Nepstad, D.; Coe, M.; Rodrigues, H.; Assunção, R. Simulating fire regimes in the Amazon in response to climate change and deforestation. Ecol. Appl. 2011, 21, 1573-1590. [CrossRef] [PubMed]

5. Cano-Crespo, A.; Oliveira, P.J.C.; Boit, A.; Cardoso, M.; Thonicke, K. Forest edge burning in the Brazilian Amazon promoted by escaping fires from managed pastures. J. Geophys. Res. G Biogeosci. 2015, 120, 2095-2107. [CrossRef]

6. Nepstad, D.; Carvalho, G.; Barros, A.C.; Alencar, A.; Capobianco, J.P.; Bishop, J.; Moutinho, P.; Lefebvre, P.; Silva, U.L.; Prins, E. Road paving, fire regime feedbacks, and the future of Amazon forests. For. Ecol. Manag. 2001, 154, 395-407. [CrossRef]

7. Nepstad, D.; Schwartzman, S.; Bamberger, B.; Santilli, M.; Ray, D.; Schlesinger, P.; Lefebvre, P.; Alencar, A.; Prinz, E.; Fiske, G.; et al. Inhibition of Amazon deforestation and fire by parks and indigenous lands. Conserv. Biol. 2006, 20, 65-73. [CrossRef] [PubMed]

8. Cochrane, M.A.; Laurance, W.F. Fire as a large-scale edge effect in Amazonian forests. J. Trop. Ecol. 2002, 18, 311-325. [CrossRef]

9. Alencar, A.A.; Brando, P.M.; Asner, G.P.; Putz, F.E. Landscape fragmentation, severe drought, and the new Amazon forest fire regime. Ecol. Appl. 2015, 25, 1493-1505. [CrossRef] [PubMed]

10. van Marle, M.J.E.; Field, R.D.; van der Werf, G.R.; Estrada de Wagt, I.A.; Houghton, R.A.; Rizzo, L.V.; Artaxo, P.; Tsigaridis, K. Fire and deforestation dynamics in Amazonia (1973-2014). Glob. Biogeochem. Cycles 2016, 24-38. [CrossRef] [PubMed]

11. Cochrane, M.A.; Schulze, M.D. Fire as a recurrent event in tropical forests of the eastern Amazon: Effects on forest structure, biomass, and species composition. Biotropica 1999, 31, 2-16. [CrossRef]

12. Chuvieco, E.; Aguado, I.; Jurdao, S.; Pettinari, M.L.; Yebra, M.; Salas, J.; Hantson, S.; de la Riva, J.; Ibarra, P.; Rodrigues, M.; et al. Integrating geospatial information into fire risk assessment. Int. J. Wildl. Fire 2014, 23, 606-619. [CrossRef]

13. Nepstad, D.C.; Verissimo, A.; Alencar, A.; Nobre, C.; Lima, E.; Lefebvre, P.; Schlesinger, P.; Potter, C.; Moutinho, P.; Mendoza, E.; et al. Large-scale impoverishment of Amazonian forests by logging and fire. Nature 1999, 398, 505-508. [CrossRef]

14. Righi, C.A.; de Alencastro Graça, P.M.L.; Cerri, C.C.; Feigl, B.J.; Fearnside, P.M. Biomass burning in Brazil's Amazonian "arc of deforestation": Burning efficiency and charcoal formation in a fire after mechanized clearing at Feliz Natal, Mato Grosso. For. Ecol. Manag. 2009, 258, 2535-2546. [CrossRef]

15. Lima, A.; Silva, T.S.F.; de Aragão, L.E.O.eC.; de Feitas, R.M.; Adami, M.; Formaggio, A.R.; Shimabukuro, Y.E. Land use and land cover changes determine the spatial relationship between fire and deforestation in the Brazilian Amazon. Appl. Geogr. 2012, 34, 239-246. [CrossRef]

16. Laurance, W.F.; Bruce Williamson, G. Positive feedbacks among forest fragmentation, drought, and climate change in the Amazon. Conserv. Biol. 2001, 15, 1529-1535. [CrossRef]

17. Phillips, O.L.; van der Heijden, G.; Lewis, S.L.; López-González, G.; Aragão, L.E.O.C.; Lloyd, J.; Malhi, Y.; Monteagudo, A.; Almeida, S.; Dávila, E.A.; et al. Drought-mortality relationships for tropical forests. New Phytol. 2010, 187, 631-646. [CrossRef] [PubMed]

18. Nepstad, D.; Lefebvre, P.; Da Silva, U.L.; Tomasella, J.; Schlesinger, P.; Solórzano, L.; Moutinho, P.; Ray, D.; Benito, J.G. Amazon drought and its implications for forest flammability and tree growth: A basin-wide analysis. Glob. Chang. Biol. 2004, 10, 704-717. [CrossRef]

19. Alencar, A.; Nepstad, D.; Del Carmen Vera Diaz, M. Forest understory fire in the Brazilian Amazon in ENSO and non-ENSO years: Area burned and committed carbon emissions. Earth Interact. 2006, 10. [CrossRef] 
20. Aragão, L.E.O.C.; Malhi, Y.; Roman-Cuesta, R.M.; Saatchi, S.; Anderson, L.O.; Shimabukuro, Y.E. Spatial patterns and fire response of recent Amazonian droughts. Geophys. Res. Lett. 2007, 34, 1-5. [CrossRef]

21. Gutiérrez-Velez, V.H.; Uriarte, M.; Defries, R.; Pinedo-Vasquez, M.; Fernandes, K.; Ceccato, P.; Baethgen, W.; Padoch, C. Land cover change interacts with drought severity to change fire regimes in Western Amazonia. Ecol. Appl. 2014, 24, 1323-1340. [CrossRef] [PubMed]

22. Asner, G.P. Cloud cover in Landsat observations of the Brazilian Amazon. Int. J. Remote Sens. 2001, 22, 3855-3862. [CrossRef]

23. Lentile, L.B.; Holden, A.Z.A.; Smith, A.M.S.; Falkowski, M.J.; Hudak, A.T.; Morgan, P.; Lewis, S.A.; Gessler, P.E.; Benson, N.C. Remote sensing techniques to assess active fire characteristics and post-fire effects. Int. J. Wildl. Fire 2006, 15, 319-345. [CrossRef]

24. Mouillot, F.; Schultz, M.G.; Yue, C.; Cadule, P.; Tansey, K.; Ciais, P.; Chuvieco, E. Ten years of global burned area products from spaceborne remote sensing-A review: Analysis of user needs and recommendations for future developments. Int. J. Appl. Earth Obs. Geoinf. 2014, 26, 64-79. [CrossRef]

25. Huesca, M.; Litago, J.; Merino-de-Miguel, S.; Cicuendez-López-Ocaña, V.; Palacios-Orueta, A. Modeling and forecasting MODIS-based Fire Potential Index on a pixel basis using time series models. Int. J. Appl. Earth Obs. Geoinf. 2014, 26, 363-376. [CrossRef]

26. Giglio, L.; Loboda, T.; Roy, D.P.; Quayle, B.; Justice, C.O. An active-fire based burned area mapping algorithm for the MODIS sensor. Remote Sens. Environ. 2009, 113, 408-420. [CrossRef]

27. Bastarrika, A.; Chuvieco, E.; Martin, M.P. Automatic burned land mapping from MODIS time series images: Assessment in Mediterranean ecosystems. IEEE Trans. Geosci. Remote Sens. 2011, 49, 3401-3413. [CrossRef]

28. Hardtke, L.A.; Blanco, P.D.; del Valle, H.F.; Metternicht, G.I.; Sione, W.F. Automated mapping of burned areas in semi-arid ecosystems using modis time-series imagery. ISPRS Int. Arch. Photogramm. Remote Sens. Spat. Inf. Sci. 2015, XL-7/W3, 811-814. [CrossRef]

29. Giglio, L.; Csiszar, I.; Justice, C.O. Global distribution and seasonality of active fires as observed with the Terra and Aqua Moderate Resolution Imaging Spectroradiometer (MODIS) sensors. J. Geophys. Res. Biogeosci. 2006, 111, 1-12. [CrossRef]

30. Justice, C.O.; Giglio, L.; Korontzi, S.; Owens, J.; Morisette, J.T.; Roy, D.; Descloitres, J.; Alleaume, S.; Petitcolin, F.; Kaufman, Y. The MODIS fire products. Remote Sens. Environ. 2002, 83, 244-262. [CrossRef]

31. Roy, D.P.; Jin, Y.; Lewis, P.E.; Justice, C.O. Prototyping a global algorithm for systematic fire-affected area mapping using MODIS time series data. Remote Sens. Environ. 2005, 97, 137-162. [CrossRef]

32. Vivchar, A.V.; Moiseenko, K.B.; Pankratova, N.V. Estimates of carbon monoxide emissions from wildfires in northern Eurasia for airquality assessment and climate modeling. Izv. Atmos. Ocean. Phys. 2010, 46, 281-293. [CrossRef]

33. Vivchar, A. Wildfires in Russia in 2000-2008: Estimates of burnt areas using the satellite MODIS MCD45 data. Remote Sens. Lett. 2011, 2, 81-90. [CrossRef]

34. Safronov, A.N.; Fokeeva, E.V.; Rakitin, V.S.; Grechko, E.I.; Shumsky, R.A. Severe wildfires near Moscow, Russia in 2010: Modeling of carbon monoxide pollution and comparisons with observations. Remote Sens. 2015, 7, 395-429. [CrossRef]

35. Padilla, M.; Stehman, S.V.; Ramo, R.; Corti, D.; Hantson, S.; Oliva, P.; Alonso-Canas, I.; Bradley, A.V.; Tansey, K.; Mota, B.; et al. Comparing the accuracies of remote sensing global burned area products using stratified random sampling and estimation. Remote Sens. Environ. 2015, 160, 114-121. [CrossRef]

36. Roy, D.P.; Boschetti, L.; Justice, C.O.; Ju, J. The collection 5 MODIS burned area product-Global evaluation by comparison with the MODIS active fire product. Remote Sens. Environ. 2008, 112, 3690-3707. [CrossRef]

37. Anaya, J.A.; Chuvieco, E. Accuracy Assessment of Burned Area Products in the Orinoco Basin. Photogramm. Eng. Remote Sens. 2012, 7, 53-60. [CrossRef]

38. Padilla, M.; Stehman, S.V.; Chuvieco, E. Validation of the 2008 MODIS-MCD45 global burned area product using stratified random sampling. Remote Sens. Environ. 2014, 144, 187-196. [CrossRef]

39. Da Silva Cardozo, F.; Pereira, G.; Shimabukuro, Y.E.; Moraes, E.C. Validation of MODIS MCD45A1 product to identify burned areas in Acre State-Amazon forest. Int. Geosci. Remote Sens. Symp. 2012, 6741-6744. [CrossRef]

40. Key, C.H.; Benson, N.C. Measuring and Remote Sensing of Burn Severity. In Proceedings of the U.S. Geological Survey Wildland Fire Workshop, Los Alamos, NM, USA, 31 October-3 November 2002. 
41. Rouse, J.W.; Haas, R.H.; Schell, J.A.; Deering, D.W.; Harlan, J.C. Monitoring the Vernal Advancement and Retrogradation (Green Wave Effect) of Natural Vegetation; Final Report; NASA/GSFC: Greenbelt, MD, USA, 1974.

42. Kasischke, E.S.; French, N.H.F.; Harrel, P.; Christensen, N.L.; Ustin, S.L.; Barry, D. Monitoring of wildfires in boreal forest using large are AVHRR-NDVI composite image data. Remote Sens. Environ. 1993, 45, 61-71. [CrossRef]

43. Martín, M.P.; Gómez, I.; Chuvieco, E. Burnt Area Index (BAIM) for burned area discrimination at regional scale using MODIS data. For. Ecol. Manag. 2006, 234, S221. [CrossRef]

44. Pinty, B.; Verstraete, M.M. GEMI: A non-linear index to monitoring global vegetation from satellite. Vegetation 1992, 101, 15-20. [CrossRef]

45. Trigg, S.; Flasse, S. An evaluation of different bi-spectral spaces for discriminating burned shrub-savannah. Int. J. Remote Sens. 2001, 22, 2641-2647. [CrossRef]

46. Key, C.H.; Benson, N.C. Landscape Assessment: Sampling and Analysis Methods; USDA For. Serv. Gen. Tech. Rep. RMRS-GTR-164-CD; USDA Forest Service: Washington, DC, USA, 2006; pp. 1-55.

47. Loboda, T.; O'Neal, K.J.; Csiszar, I. Regionally adaptable dNBR-based algorithm for burned area mapping from MODIS data. Remote Sens. Environ. 2007, 109, 429-442. [CrossRef]

48. Veraverbeke, S.; Lhermitte, S.; Verstraeten, W.W.; Goossens, R. The temporal dimension of differenced Normalized Burn Ratio (dNBR) fire/burn severity studies: The case of the large 2007 Peloponnese wildfires in Greece. Remote Sens. Environ. 2010, 114, 2548-2563. [CrossRef]

49. Lhermitte, S.; Verbesselt, J.; Verstraeten, W.W.; Veraverbeke, S.; Coppin, P. Assessing intra-annual vegetation regrowth after fire using the pixel based regeneration index. ISPRS J. Photogramm. Remote Sens. 2011, 66, 17-27. [CrossRef]

50. Diaz-Delgado, R.; Salvador, R.; Pons, X. Monitoring of plant community regeneration after fire by remote sensing. In Fire Management and Landscape Ecology; Traboud, L., Ed.; International Association of Wildland Fire: Fairfield, WA, USA, 1998; pp. 315-324.

51. Instituto Brasileiro de Geografia e Estatística (IBGE) Mapa de Climas do Brasil. Available online: http: / / portaldemapas.ibge.gov.br (accessed on 23 October 2015).

52. Instituto Nacional de Meteorologia (Inmet) Normais Climatológicas do Brasil. Available online: http: / / www.inmet.gov.br (accessed on 23 October 2015).

53. Instituto Nacional de Pesquisas Espaciais (INPE) Portal do Monitoramento de Queimadas e Incêndios. Available online: http:/ / queimadas.cptec.inpe.br (accessed on 22 June 2015).

54. Instituto Nacional de Pesquisas Espaciais (INPE) Monitoramento da Floresta Amazônica Brasileira por Satélite-Projeto PRODES. Available online: http:/ / www.obt.inpe.br/prodes (accessed on 25 October 2015).

55. Instituto Brasileiro de Geografia e Estatística (IBGE) Vegetação: Estado do Pará. Available online: http: / / portaldemapas.ibge.gov.br (accessed on 23 October 2015).

56. Instituto Chico Mendes de Conservação da Biodiversidade (ICMBIO) Geoprocessamento. Available online: http:/ / www.icmbio.gov.br (accessed on 25 October 2015).

57. Fundação Nacional do Índio (FUNAI) Mapas. Available online: http:/ / mapas2.funai.gov.br (accessed on 24 October 2015).

58. Instituto Nacional de Colonização e Reforma Agrária (INCRA) Acervo Fundiário. Available online: http: / / acervofundiario.incra.gov.br (accessed on 25 October 2015).

59. Instituto do Homem e Meio Ambiente da Amazônia (IMAZON) Mapas—Áreas Protegidas da Amazônia Legal. Available online: http:/ / imazon.org.br (accessed on 25 October 2015).

60. Zimmerman, B.; Peres, C.A.; Malcolm, J.R.; Turner, T. Conservation and development alliances with the Kayapó of south-eastern Amazonia, a tropical forest indigenous people. Environ. Conserv. 2001, 28, 10-22. [CrossRef]

61. Fearnside, P.M. Brazil's Cuiabá- Santarém (BR-163) Highway: The environmental cost of paving a soybean corridor through the Amazon. Environ. Manag. 2007, 39, 601-614. [CrossRef] [PubMed]

62. Chuvieco, E.; Pettinari, M.L.; Heil, A.; Storm, T. ESA Climate Change Initiative-Fire Disturbance: D1.2 Product Specification Report; Version 6.1; University of Alcala: Spain, 2016.

63. Alonso-Canas, I.; Chuvieco, E. Global burned area mapping from ENVISAT-MERIS and MODIS active fire data. Remote Sens. Environ. 2015, 163, 140-152. [CrossRef] 
64. Justice, C.O.; Townshend, J.R.G.; Vermote, E.F.; Masuoka, E.; Wolfe, R.E.; Saleous, N.; Roy, D.P.; Morisette, J.T. An overview of MODIS Land data processing and product status. Remote Sens. Environ. 2002, 83, 3-15. [CrossRef]

65. Vermote, E.F. MOD09A1 MODIS Surface Reflectance 8-Day L3 Global 500m SIN Grid V006; NASA LP DAAC: Sioux Falls, SD, USA, 2016. [CrossRef]

66. Chuvieco, E.; Ventura, G.; Martín, M.P.; Gómez, I. Assessment of multitemporal compositing techniques of MODIS and AVHRR images for burned land mapping. Remote Sens. Environ. 2005, 94, 450-462. [CrossRef]

67. Morton, D.C.; Nagol, J.; Carabajal, C.C.; Rosette, J.; Palace, M.; Cook, B.D.; Vermote, E.F.; Harding, D.J.; North, P.R.J. Amazon forests maintain consistent canopy structure and greenness during the dry season. Nature 2014, 506, 1-16. [CrossRef] [PubMed]

68. Maier, S.W. Changes in surface reflectance from wildfires on the Australian continent measured by MODIS. Int. J. Remote Sens. 2010, 31, 3161-3176. [CrossRef]

69. Pereira, J.M.C.; Sa, A.C.L.; Souza, A.M.O.; Silva, J.M.N.; Santos, T.N.; Carreiras, J.M. Spectral characterization and discrimination of burnt areas. In Remote Sensing of Large Wildfires in the European Mediterranean Basin; Springer: Berlin, Germany, 1999; pp. 123-138.

70. Forkel, M.; Carvalhais, N.; Verbesselt, J.; Mahecha, M.D.; Neigh, C.S.R.; Reichstein, M. Trend Change detection in NDVI time series: Effects of inter-annual variability and methodology. Remote Sens. 2013, 5, 2113-2144. [CrossRef]

71. Kolden, C.; Roganf, J. Mapping Wildfire Burn Severity in the Arctic Tundra from Downsampled MODIS Data. Arct. Antarct Alp. Res. 2013, 45, 64-76. [CrossRef]

72. Godwin, D.R.; Kobziar, L.N. Comparison of burn severities of consecutive large-scale fires in Florida sand pine scrubusing satellite imagery analysis. Fire Ecol. 2011, 7, 99-113. [CrossRef]

73. Chen, X.; Vogelmann, J.E.; Rollins, M.; Ohlen, D.; Key, C.H.; Yang, L.; Huang, C.; Shi, H. Detecting post-fire burn severity and vegetation recovery using multitemporal remote sensing spectral indices and field-collected composite burn index data in a ponderosa pine forest. Int. J. Remote Sens. 2011, 32, 7905-7927. [CrossRef]

74. Zidane, I.; Lhissou, R.; Bouli, A.; Mabrouki, M. An improved algorithm for mapping burnt areas in the Mediterranean forest landscape of Morocco. J. For. Res. 2018. [CrossRef]

75. Holden, Z.A.; Morgan, P.; Smith, A.M.S.; Vierling, L. Beyond Landsat: A comparison of four satellite sensors for detecting burn severity in ponderosa pine forests of the Gila Wilderness, NM, USA. Int. J. Wildl. Fire 2010, 19, 449-458. [CrossRef]

76. Hislop, S.; Jones, S.; Soto-Berelov, M.; Skidmore, A.; Haywood, A.; Nguyen, T.H. Using landsat spectral indices in time-series to assess wildfire disturbance and recovery. Remote Sens. 2018, 10, 460. [CrossRef]

77. Dempewolf, J.; Trigg, S.; DeFries, R.S.; Eby, S. Burned-Area Mapping of the Serengeti-Mara Region Using MODIS Reflectance Data. IEEE Geosci. Remote Sens. Lett. 2007, 4, 312-316. [CrossRef]

78. McCarley, T.R.; Smith, A.M.S.; Kolden, C.A.; Kreitler, J. Evaluating the Mid-Infrared Bi-spectral Index for improved assessment of low-severity fire effects in a conifer forest. Int. J. Wildl. Fire 2018, 27, 407. [CrossRef]

79. García, M.J.L.; Caselles, V. Mapping burns and natural reforestation using thematic Mapper data. Geocarto Int. 1991, 6, 31-37. [CrossRef]

80. Pereira, J.M.C. Remote sensing of burned areas in tropical savannas. Int. J. Wildl. Fire 2003, 12, 259. [CrossRef]

81. Cardozo, S.; Pereira, G.; Shimabukuro, Y.E.; Moraes, E.C. Avaliação Das Áreas Queimadas No Estado De Rondônia. Rev. Bras. Cartogr. 2014, 66, 705-716.

82. Shimabukuro, Y.E.; Duarte, V.; Arai, E.; Freitas, R.M.; Lima, A.; Valeriano, D.M.; Brown, I.F.; Maldonado, M.L.R. Fraction images derived from Terra Modis data for mapping burnt areas in Brazilian Amazonia. Int. J. Remote Sens. 2009, 30, 1537-1546. [CrossRef]

83. De Carvalho Júnior, O.A.; Guimarães, R.F.; Silva, C.; Gomes, R.A.T. Standardized Time-Series and Interannual Phenological Deviation: New Techniques for Burned-Area Detection Using Long-Term MODIS-NBR Dataset. Remote Sens. 2015, 7, 6950-6985. [CrossRef]

84. Lhermitte, S.; Verbesselt, J.; Verstraeten, W.W.; Coppin, P. A Pixel Based Regeneration Index using Time Series Similarity and Spatial Context. Photogramm. Eng. Remote Sens. 2010, 76, 673-682. [CrossRef]

85. Veraverbeke, S.; Somers, B.; Gitas, I.; Katagis, T.; Polychronaki, A.; Goossens, R. Spectral mixture analysis to assess post-fire vegetation regeneration using Landsat Thematic Mapper imagery: Accounting for soil brightness variation. Int. J. Appl. Earth Obs. Geoinf. 2012, 14, 1-11. [CrossRef] 
86. Roy, D.P.; Boschetti, L. Southern Africa validation of the MODIS, L3JRC, and GlobCarbon burned-area products. IEEE Trans. Geosci. Remote Sens. 2009, 47, 1032-1044. [CrossRef]

87. Eva, H.; Lambin, E.F. Fires and land-cover change in the tropics:a remote sensing analysis at the landscape scale. J. Biogeogr. 2000, 27, 765-776. [CrossRef]

88. Parrini, F.; Owen-Smith, N. The importance of post-fire regrowth for sable antelope in a Southern African savanna. Afr. J. Ecol. 2010, 48, 526-534. [CrossRef]

89. Padilla, M.; Stehman, S.V.; Litago, J.; Chuvieco, E. Assessing the temporal stability of the accuracy of a time series of burned area products. Remote Sens. 2014, 6, 2050-2068. [CrossRef]

90. Congalton, R.G. A review of assessing the accuracy of classifications of remotely sensed data. Remote Sens. Environ. 1991, 37, 35-46. [CrossRef]

91. Fleiss, J.L.; Levin, B.; Paik, M.C. Statistical Methods for Rates and Proportions; Wiley Series in Probability and Statistics; John Wiley \& Sons, Inc.: Hoboken, NJ, USA, 2003.

92. Arvidson, T.; Goward, S.N.; Gasch, J.; Williams, D. Landsat-7 long-term acquisition plan: Development and validation. Photogramm. Eng. Remote Sens. 2006, 72, 1137-1146. [CrossRef]

93. McNemar, Q. Note on the sampling error of the difference between correlated proportions or percentages. Psychometrika 1947, 12, 153-157. [CrossRef] [PubMed]

94. Foody, G.M. Thematic map comparison: Evaluating the statistical significance of differences in classification accuracy. Photogramm. Eng. Remote Sens. 2004, 70, 627-633. [CrossRef]

95. Quintano, C.; Fernández-Manso, A.; Fernández-Manso, O. Combination of Landsat and Sentinel-2 MSI data for initial assessing of burn severity. Int. J. Appl. Earth Obs. Geoinf. 2018, 64, 221-225. [CrossRef]

96. Pleniou, M.; Koutsias, N. Sensitivity of spectral reflectance values to different burn and vegetation ratios: A multi-scale approach applied in a fire affected area. ISPRS J. Photogramm. Remote Sens. 2013, 79, 199-210. [CrossRef]

97. Roy, D.P.; Boschetti, L.; Trigg, S.N. Remote sensing of fire severity: Assessing the performance of the normalized burn ratio. IEEE Geosci. Remote Sens. Lett. 2006, 3, 112-116. [CrossRef]

98. Quintano, C.; Fernández-Manso, A.; Stein, A.; Bijker, W. Estimation of area burned by forest fires in Mediterranean countries: A remote sensing data mining perspective. For. Ecol. Manag. 2011, 262, 1597-1607. [CrossRef]

99. Chen, Y.; Morton, D.C.; Jin, Y.; Collatz, G.J.; Kasibhatla, P.S.; van der Werf, G.R.; DeFries, R.S.; Randerson, J.T.; Gollatz, G.J.; Kasibhatla, P.S.; et al. Long-term trends and interannual variability of forest, savanna and agricultural fires in South America. Carbon Manag. 2013, 4, 617-638. [CrossRef]

100. Libonati, R.; DaCamara, C.C.; Setzer, A.W.; Morelli, F.; Melchiori, A.E. An algorithm for burned area detection in the Brazilian Cerrado using $4 \mu \mathrm{m}$ MODIS imagery. Remote Sens. 2015, 7, 15782-15803. [CrossRef]

101. De Mendonça, M.J.C.; Vera Diaz, M.D.C.; Nepstad, D.; Seroa Da Motta, R.; Alencar, A.; Gomes, J.C.; Ortiz, R.A. The economic cost of the use of fire in the Amazon. Ecol. Econ. 2004, 49, 89-105. [CrossRef]

102. Nelson, A.; Chomitz, K.M. Effectiveness of strict vs. multiple use protected areas in reducing tropical forest fires: A global analysis using matching methods. PLoS ONE 2011, 6. [CrossRef] [PubMed]

103. Quintano, C.; Fernández-Manso, A.; Fernández-Manso, O.; Shimabukuro, Y.E. Mapping burned areas in Mediterranean countries using spectral mixture analysis from a uni-temporal perspective. Int. J. Remote Sens. 2006, 27, 645-662. [CrossRef]

104. Quintano, C.; Fernández-Manso, A.; Roberts, D.A. Multiple Endmember Spectral Mixture Analysis (MESMA) to map burn severity levels from Landsat images in Mediterranean countries. Remote Sens. Environ. 2013, 136, 76-88. [CrossRef]

105. Cao, X.; Chen, J.; Matsushita, B.; Imura, H.; Wang, L. An automatic method for burn scar mapping using support vector machines. Int. J. Remote Sens. 2009, 30, 577-594. [CrossRef]

106. Dragozi, E.; Gitas, I.; Stavrakoudis, D.; Theocharis, J. Burned Area Mapping Using Support Vector Machines and the FuzCoC Feature Selection Method on VHR IKONOS Imagery. Remote Sens. 2014, 6, 12005-12036. [CrossRef]

(C) 2018 by the authors. Licensee MDPI, Basel, Switzerland. This article is an open access article distributed under the terms and conditions of the Creative Commons Attribution (CC BY) license (http:/ / creativecommons.org/licenses/by/4.0/). 